WORKING PAPER NO. 146

TRADE AND COMPETITION POLICY

Aditya Bhattacharjea

NOVEMBER 2004

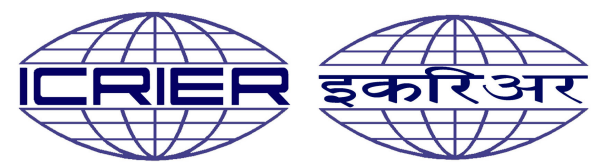

INDIAN COUNCIL FOR RESEARCH ON INTERNATIONAL ECONOMIC RELATIONS Core-6A, 4th Floor, India Habitat Centre, Lodi Road, New Delhi-110 003 Website 1: www.icrier.org, website 2: www.icrier.res.in 


\title{
TRADE AND COMPETITION POLICY
}

\author{
Aditya Bhattacharjea
}

NOVEMBER 2004

The views expressed in the ICR IER Working Paper Series are those of the author(s) and do not necessarily reflect those of the Indian Council for Research on International Economic Relations (ICR IER). 


\section{Contents}

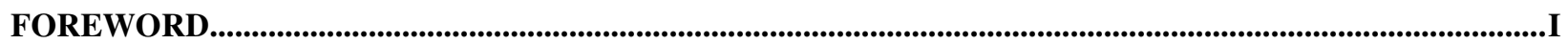

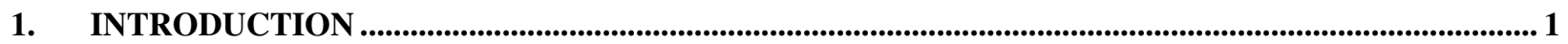

1.1 COMPETITION POLICY AND ITS RELEVANCE TO DEVELOPING COUNTRIES ……........................................ 1

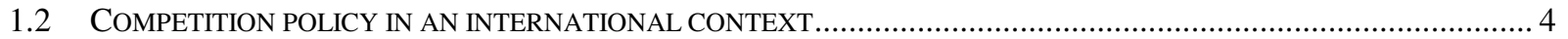

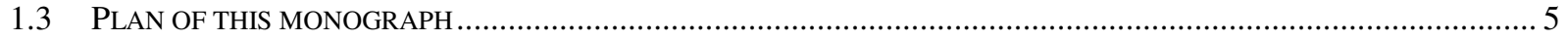

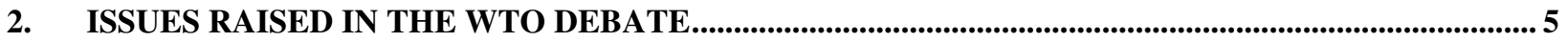

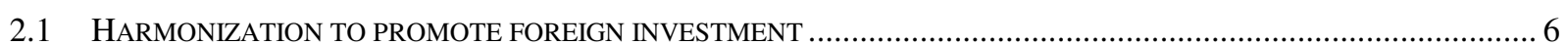

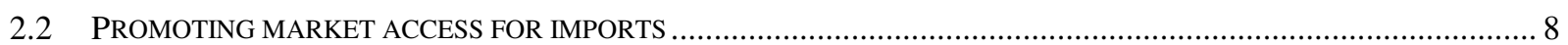

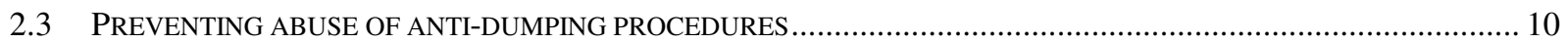

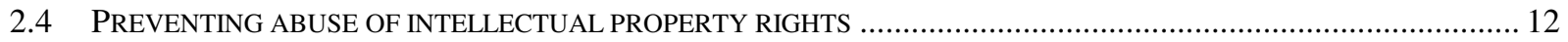

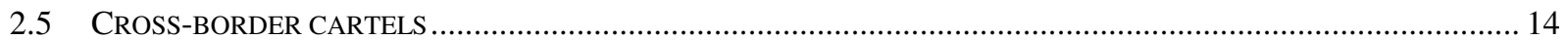

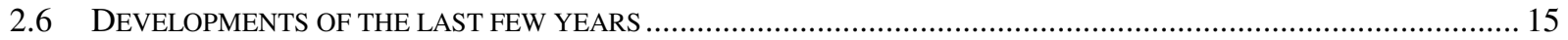

2.7 CONCLUSION: ASSESSMENT OF THE WTO DEBATE............................................................................ 18

3. INTERNATIONAL AGREEMENTS CONCERNED WITH COMPETITION POLICY ......................... 19

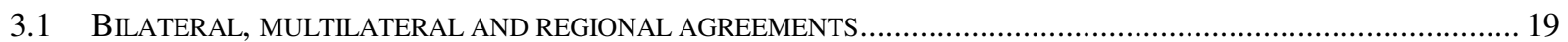

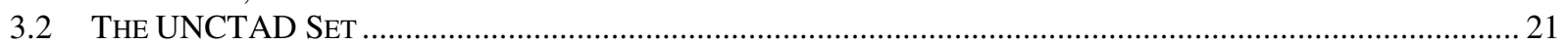

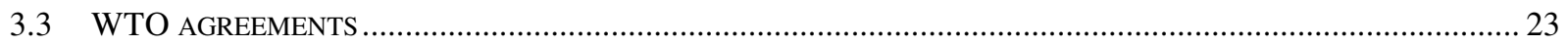

4. RECENT CHANGES IN INDIAN COMPETITION POLICY IN RELATION TO THE

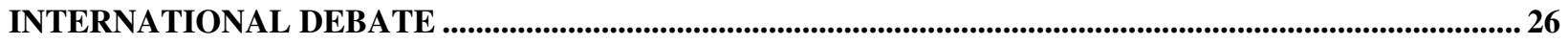

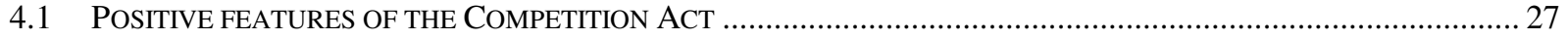

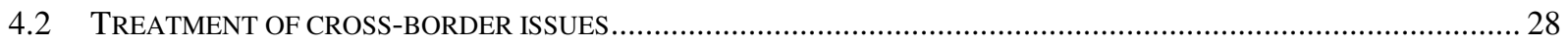

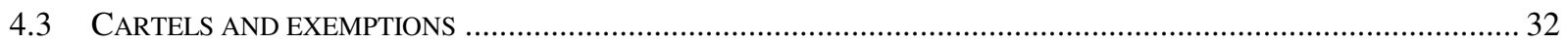

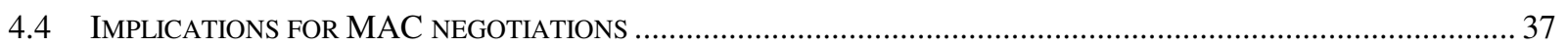

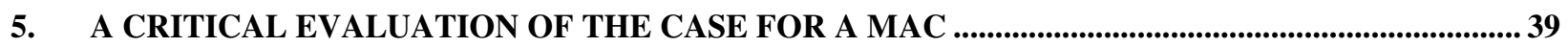

5.1 CARTELS AND THE ‘DEVELOPMENT DIMENSION’ OF COMPETITION POLICY …….......................................... 39

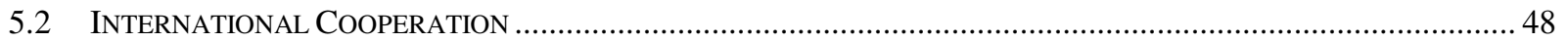

6. RECOMMENDATIONS FOR THE FUTURE ...............................................................................................5

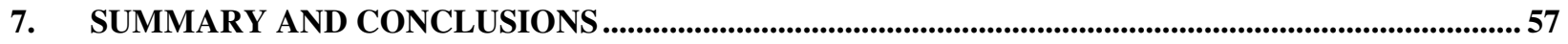

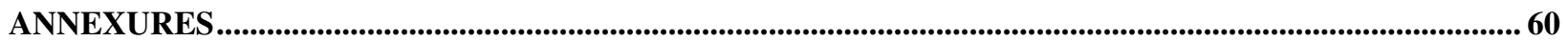

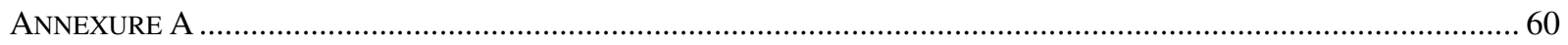

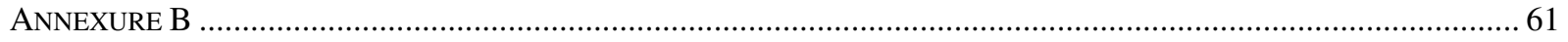

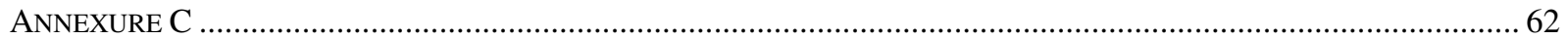

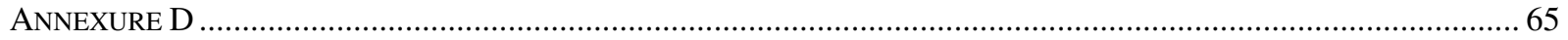




\section{Foreword}

This paper on Trade and Competition Policy covers the entire gamut of issues of interest and concern to developing countries in the trade and competition policy interface, domestically and multilaterally. In the backdrop of its multilateral stance on the subject, the paper critiques India's domestic policy reforms and recent legislation in this area.

The paper traces the history of the debate on competition policy from the time of the Hawana Charter until the recent decision of abandoning negotiations on the subject under the WTO Doha round. With a detailed analytical account of the debate within the WTO from the time of the 1996 Singapore Ministerial Conference, which mandated a study of the interaction between trade and competition policy, the paper lays bare the respective positions of the proponents and opponents of a multilateral agreement on competition (MAC), and comes to the conclusion that a MAC is not in the interest of the developing countries generally. It further argues that, although there may be no political market for a MAC in the foreseeable future, the European Union, the major proponent of a MAC has already achieved its objective, even without an agreement, inasmuch as more than 50 developing countries have adopted competition legislation in the last decade with most of them prohibiting hard-core cartels and providing for non-discrimination, explicitly and implicitly. (This is true of the Indian legislation also). The developing countries, on the other hand, were not able to make any headway on the competition concerns most relevant to them, such as cross border consequences of mega-mergers and the abuse of antidumping procedures and intellectual property rights.

Although opposed to a multilateral agreement on competition in the WTO, the paper argues for international cooperation to mitigate the cross border impact of competition policies of different countries by way of an agreement outside WTO. The paper has made some suggestions of the use of price comparison methodology of the UR antidumping agreement to curb the price fixing behaviour among cartels. In case of a MAC under the WTO, the paper recommends revocations of patents or compulsory licensing under the WTO dispute settlements understanding to curb the price fixing behaviour of cartels, particularly in the area of pharmaceuticals and speciality chemicals.

The critique on the Indian policy and legislation suggests that the basis of India's opposition to a MAC has been overlooked in crafting the new Competition Act of 2002. What is more, some important provisions of the act seem to be distorted versions of the relevant provision of the EU Treaty which is the legal foundation of the anti-trust policy in the EU. While noting positive features of the 2002 Act by way of improvements compared to the MRTP Act, it points to some weakness.

We are very grateful to the Sir Ratan Tata Trust for supporting our research on WTO issues.

Dr. Arvind Virmani

Director and CE

ICRIER

November 2004 


\section{Introduction}

\subsection{Competition policy and its relevance to developing countries}

Competition policy (also known as antitrust policy), at a minimum, involves the prohibition or regulation of restrictive business practices (RBPs, also known as anti-competitive practices) that firms undertake in order to limit competition. The most common RBPs include

- Collusive agreements between competitors selling the same or similar products to restrict competition between themselves. The most egregious are agreements to fix prices, restrict output, divide up markets, or make collusive bids in an auction or procurement process. Groups of firms that enter into such agreements are commonly known as "hard core cartels".

- Agreements between firms at different stages in the distribution chain that would limit competition. For example, agreements in which producers require distributors not to sell a competitor's product, not to sell outside a particular territory, or to maintain recommended retail prices.

- Actions taken by a dominant firm to drive out rivals or prevent entry by potential competitors. This may involve charging artificially low ('predatory') prices, or denying rivals access to a crucial raw material or essential facilities such as a wire network (for telecommunications) that are owned by the dominant firm.

Apart from controlling RBPs, many countries regulate corporate mergers and acquisitions that might have an adverse effect on competition by reducing the number of competitors in the market, which could also increase the likelihood of collusion between them. In many countries, the agency that is entrusted with the control of RBPs is also charged with entertaining complaints about misleading advertising or supply of defective goods, while other countries leave these matters to be handled by the regular court system as cases of contract violation, or by specialized consumer forums. Competition policy may also encompass a range of other government measures that affect competition, such as policies towards international trade, foreign investment, licensing, regulation, taxation, government procurement and standard-setting. But its core remains the regulation of RBPs by enterprises, so as to promote and protect a competitive market, which encourages lower prices, better quality, enhanced choice and variety, efficient allocation of society's resources, and (more 
controversially) innovation and growth.

The importance of competition policy has been increasingly recognized, especially in developing countries. Until recently, many developing countries followed industrial policies that deliberately limited competition by restricting imports and the entry of new firms. This was achieved by policies such as import duties and import licensing, reservation of certain areas for the public sector, investment licensing for the private sector, and restrictions on foreign direct investment (FDI). With market competition thus restricted, competition policy was required to prevent collusive behaviour and abuse of dominance by those firms that were allowed to function, both public and private, but few developing countries thought that it was important. India's Monopolies and Restrictive Trade Practices Act was passed as early as 1969, but it was geared to controlling the concentration of economic power by limiting the growth of large industrial houses, and in this respect it may have actually dampened competition by preventing expansion of the more efficient large firms. It did contain numerous provisions to control RBPs, but as I show below, it was not very effective.

In more recent years, although the nearly universal trend towards liberalization of markets (especially the reduction of trade barriers and relaxation or abolition of controls on entry by domestic and foreign enterprises) should itself promote competition, this may not follow automatically, and competition policy takes on a new significance. Firms that were hitherto sheltered by government measures would now resort to RBPs to ward off competition. Also, to the extent that privatization is part of the liberalization package, it could result in public-sector monopolies, whose pricing policies were often curbed so as to protect consumers, becoming privately owned. Many of these firms are utilities (such as gas, power, and telecommunications) which have "natural monopoly" characteristics (that is, only one firm can efficiently serve a market because of the high overhead cost of distribution networks), and competition from imports is not feasible. Others are highly capitalintensive industries where fresh entry is difficult. Once they are privatized, they would charge profitmaximizing monopoly prices and attempt to retain their inherited monopoly power through abuse of dominance.

Liberalization also involves a more accommodating policy towards FDI. ${ }^{1}$ Whatever its other

\footnotetext{
${ }^{1}$ The concerns in this paragraph were expressed by UNCTAD in its 1997 World Investment Report.
} 
benefits, this could also result in abuse of market dominance by multinational corporations with the resources to engage in forms of competition that could drive out domestic rivals. Greater openness to foreign firms raises the prospect that foreign merger decisions will impact the local market via merger of their local subsidiaries. While 'greenfield'FDI (i.e. setting up of new units with a foreign equity stake) would generally introduce more competition into a market, it has been observed that a very large proportion of FDI in recent years has taken the form of mergers or acquisitions of domestic firms in order to gain control of their assets, especially capacity and marketing networks. If these domestic firms were rivals of the acquirer, this would reduce competition. In order to attract FDI, some developing countries may also deliberately reduce competition by granting exclusive selling or mining rights to foreign firms. Thus, the need to safeguard competition remains even in a liberalized economy. In any case, markets in developing countries are typically small in economic terms, and therefore many industries tend to be dominated by a handful of firms even if there are no legal restrictions on entry.

It should also be mentioned, however, that there are several economists who do not see the need for competition policy in developing countries. Some believe that exposure to competition from imports, resulting from a policy of free trade, is itself sufficient to control domestic monopolistic tendencies, without government regulation of RBPs. However, others contend that some sectors, such as infrastructure and local services, are inherently non-tradable, and therefore competition needs to be enforced by the state. In the international debate, as we shall see in Section 2.2 below, much concern was expressed about private RBPs designed specifically to block competition from imports.

Other economists are sceptical about competition policy for a very different reason. They point out that the current emphasis on single-mindedly promoting competition and efficiency is inappropriate, especially for developing countries. They also point out that the developed countries who are now promoting the cause of competition policy either adopted it relatively recently in their history and restrained its operation so as to build large firms to serve as 'national champions' (France and Japan), or (in the case of the United States until the 1970s) used it to curb large enterprises and promote small businesses, often sacrificing efficiency. I shall examine these views below. 


\subsection{Competition policy in an international context}

The focus of this monograph, however, is the international dimension of competition policy, in particular the case for a multilateral agreement on competition (MAC). The relationship between trade and competition policy was one of the four "Singapore Issues", which were given that label because they were put on the WTO agenda for study and discussion (not negotiations) at the 1996 Singapore Ministerial Conference. (The other three were trade and investment, trade facilitation, and transparency in government procurement.) But the issue of international competition policy is actually much older. It figured prominently at an international forum for the first time as early as 1946 in the Havana Charter, which laid the groundwork for an International Trade Organization (ITO). Article 46 of the Charter stated that "Each Member shall take appropriate measures and shall co-operate with the Organization to prevent, on the part of private or public commercial enterprises, business practices affecting international trade which restrain competition, limit access to markets, or foster monopolistic control...." It envisaged a mechanism for consultations, reports and recommendations on such practices, with a view to discouraging them. The ITO never came into being, principally because of opposition from the United States, and the General Agreement on Tariffs and Trade (GATT) that emerged from the Havana Charter did not venture into the area of competition policy. During the 1950s and 1960s, developing countries repeatedly raised concerns about such RBPs, especially those of multinational corporations, at the GATT and United Nations and later at the United Nations Conference on Trade and Development (UNCTAD), but opposition from advanced countries did not allow any substantive measures to be undertaken. The UNCTAD "Set of Multilaterally Agreed Equitable Principles and Rules for the Control of Restrictive Business Practices" was adopted by the U.N. General Assembly in 1980 and has been reviewed periodically thereafter, but it remains non-binding and unenforceable. Developing countries have called for it to be made into a binding instrument, but with no success.

Given this historical background, it is ironic that the initiative for a MAC at the WTO came not from the developing countries, but from Japan and the European Union ${ }^{2}$ at the 1996 Singapore Ministerial. Along with the other three "Singapore issues", in the course of discussions over the next seven years, it came to be opposed by the vast majority of developing countries. Their opposition

\footnotetext{
${ }^{2}$ For legal reasons, the European Union continues to be known as the "European Community and its member states" at the WTO. I shall refer to it as the EU for consistency.
} 
contributed to the collapse of the Cancun Ministerial in 2003 and the formal dropping of competition policy from the work programme of the Doha Round of negotiations by the WTO General Council at its meeting in Geneva in July 2004. This monograph reviews the debate on trade and competition policy, with the intention of providing a non-technical introduction which might be useful when the issue is raised again (as the EU statements indicate it will be) either at the WTO or elsewhere.

\subsection{Plan of this monograph}

The plan of this monograph is as follows. In the next section, I review the various arguments that were advanced in favour of a MAC, both in the WGTCP and in the academic community. These included harmonization of national regulatory regimes so as to promote foreign investment; action against private RBPs that hinder market access to imports; prevention of abuse of anti-dumping procedures and intellectual property rights; and the need to crack down on the activities of crossborder cartels. This section ends with a review of the sharp differences between developed and developing countries over the need for a MAC, various compromise suggestions that were put forward in recent years, and an assessment of what the debate achieved. Section 3 describes the existing international agreements in the area of competition policy, including bilateral, regional, and sector-specific WTO agreements, as well as the UNCTAD Set. Section 4 turns its focus to the Indian situation, where a new Competition Act is about to replace the MRTP Act. It reviews the salient features of both Acts, with special reference to their treatment of cross-border issues and cartels. Section 5 critically evaluates from the Indian perspective the case for a MAC, in the limited form that remained on the table before the Cancun Ministerial, and which may be revived in another forum. In particular, it examines the implications of an anti-cartel agreement for developing countries, and the likelihood of international cooperation. In Section 6, I recommend what position developing countries should take in future discussions at various forums, and propose what kind of agreement they should work towards, and also what actions they can take unilaterally or cooperatively. Section 7 summarizes and concludes the study.

\section{Issues raised in the WTO debate}

The 1996 Singapore Ministerial resolved to set up working groups on each of the Singapore issues. The mandate of the Working Group on the Interaction between Trade and Competition Policy 
(WGTCP) was 'to study issues raised by Members relating to the interaction between trade and competition policy, including anticompetitive practices in order to identify any areas that may merit further consideration in the WTO framework". ${ }^{3}$ The WGTCP submitted six annual reports between 1998 and 2003. Following the unusual wording of its mandate, however, it confined itself to reporting the very different opinions of member countries on various aspects of the matter, with many of the same irreconcilable arguments being repeated from one report to the next. It became obvious that most developing countries were opposed to a MAC under the auspices of the WTO. Consequently, the relevant paragraphs of the 2001 Doha Ministerial Declaration ${ }^{4}$ tried to give a development-friendly slant to the issue. It was stated in terms of 'the case for a multilateral framework to enhance the contribution of competition policy to international trade and development'; recognized developing countries' need for technical assistance and capacity-building in this area in order to enable them to evaluate the implications of closer multilateral cooperation; and also declared that 'Full account shall be taken of the needs of developing and least-developed country participants and appropriate flexibility provided to address them." The Declaration also substantially narrowed the range of issues for subsequent meetings of the Working Group during the period up to the Fifth (Cancun) Ministerial. In parallel with these discussions, a considerable academic literature emerged on many of the issues. The following analysis therefore draws on discussions both inside and outside the WGTCP. I shall first examine the five very different pillars on which the case for a MAC was built up, four of which crumbled in the early years of the WTO debate. I then review developments of the last few years, in particular the positions of the proponents and opponents of the very idea of a MAC, the compromise solutions that were offered, and the deadlock that ultimately removed the issue from the WTO.

\subsection{Harmonization to promote foreign investment}

The first pillar of the MAC argument is the need to harmonize different national competition laws so that firms do not have to comply with different standards in the different countries in which

\footnotetext{
${ }^{3}$ WTO document WT/MIN(96)/DEC, paragraph 20. The full text of the paragraph is reproduced at Annexure A. I shall follow the convention of capitalizing the initial $m$ in the word 'members' when it refers to Members of the WTO, and not when it refers to members of other international organizations or of cartels. This should help to maintain the distinction in readers' minds.

${ }^{4}$ WTO document WT/MIN(01)/DEC/1, paragraphs 23-25. The full text of these paragraphs is reproduced at Annexure B.
} 
they operate, and to deal with contradictory rulings from different national authorities. Apart from different legal traditions in different countries, there is very little consensus on the substantive issues of competition policy. Almost all the anti-competitive practices listed at the beginning of this monograph can also give rise to certain kinds of efficiency benefits: mergers can give rise to scale economies and 'synergies', while certain types of inter-firm agreements and exclusive contracts can promote investment in research or marketing facilities. There can be genuine disagreement even within a single country on the balance of these gains against the harm caused by reduced competition, and obviously there is much more scope for differences between different national authorities, where the international distribution of costs and benefits is an additional complicating factor. National authorities would have very different assessments of the balance of positive and negative effects of a merger, depending on how producers and consumers are distributed across countries.

Absent a global competition regulator with the authority to compensate losers while enforcing decisions that would maximize world welfare, there is no solution to this problem. But in any case, MNCs have to obey different national laws relating to labour, environment, taxation, and product standards; competition laws are just another matter they have to deal with by tailoring their practices to local requirements. Some competition law is better than none from the perspective of potential foreign investors: even if a particular country's law is not a carbon copy of what the MNC is familiar with elsewhere, it at least defines what kind of business practices are impermissible. This is not an absolute guarantee of predictability, for most competition statutes contain large grey areas, and conflicting interpretations of the same law are common even in developed countries with far greater experience with competition jurisprudence. But at least the existence of a competition law sets limits on bureaucratic and political arbitrariness.

Tailoring behaviour to satisfy local laws is obviously not possible in the case of mergers, since a merger between two firms which is simultaneously permitted in one country and prohibited in another cannot be modified in a way that satisfies both. On this, there is no prospect for an international agreement even between the US and the EU, which have regular interaction between their competition agencies. The mergers between the US firms Boeing and McDonnell Douglas, and between General Electric and Honeywell, were both approved by the US authorities but opposed by the EU, while a merger between the European firms Ciba-Geigy and Sandoz was approved by the 
EU but opposed by the US. Ultimately, compromises had to be worked out. Harmonization of merger review procedures is still being discussed by UNCTAD, the OECD, as well as the International Competition Network (an association of national competition authorities). However, it is unlikely to figure as part of a MAC, and as we shall see, it was not included in the revised mandate of the WGTCP in the Doha Declaration. ${ }^{5}$

\subsection{Promoting market access for imports}

The second pillar is market access, or facilitating the free movement of goods and services into countries. Expanding market access was the original rationale of the 1947 GATT. It was also the EU's primary motivation for bringing competition policy onto the WTO agenda, based on its own experience in abolishing private barriers to the movement of goods between its member states, which complemented the abolition of official restrictions on trade between them. On a global level, as government-imposed trade barriers have been significantly reduced under the auspices of the WTO, there are fears that private RBPs such as import cartels and control of distribution channels might be used to block foreign suppliers' access to domestic markets. In one of the earliest WGTCP meetings, India complained that her firms had been prevented from participating in the Dutch flower auction and the Basle jewellery and watch fair. ${ }^{6}$ Japanese business groups are often accused by US exporters of engaging in such practices. In the famous Kodak-Fuji case (1998), the US took the Japanese government before a WTO dispute settlement panel (DSP), alleging that official tolerance if not encouragement of these measures violated the core WTO principle of National Treatment (non-discriminatory treatment as between domestic and foreign goods) and nullified the market access concessions Japan had made under GATT. While the DSP did not uphold the US complaint, it did examine Japan's competition-related policies to see if they constituted infringements of the GATT. More recently, in the 2004 Telmex case, another DSP has ruled, again on a complaint by the US, that Mexico must take action against a cartel in its telecom sector that was allegedly discouraging access by US telecom providers.

\footnotetext{
${ }^{5}$ Apart from the issue of simplifying and harmonizing national merger review procedures, the vast increase in the number and size of mergers with cross-border effects in the 1990s did become an international concern in its own right. However, with no agreement possible even between the EU and US, discussions on controlling such mergers did not get very far in the WTO.

${ }^{6}$ WTO document WT/WGTCP/W/111 (Communication from India, September 1998).
} 
These two rulings show that even without a specific MAC, the existing WTO dispute settlement process can be used to force Members to take action against their firms' RBPs which undermine market access for other Members' firms, at least in the areas covered by GATT (goods traded across national borders) and for specific services 'scheduled' by Members under the General Agreement on Trade in Services (GATS). ${ }^{7}$ Market access for foreign direct investment geared to local production of goods and provision of non-scheduled services remains outside this framework, and would presumably be covered by a multilateral agreement on investment (another of the Singapore issues which was dropped by the 2004 Geneva agreement). However, in recent years, the EU has considerably toned down its focus on market access as the rationale for a MAC, while the US has shifted its emphasis to bilateral trade agreements that incorporate competition-related clauses guaranteeing market access. With Japan, it applied bilateral pressure under the Structural Impediments Initiative, while it is now more likely to use the WTO dispute settlement mechanism against countries with which it does not have bilateral agreements. As far as India is concerned, RBPs that restrict market access do not appear to bother the US. The United States Trade Representative's (USTR) National Trade Estimates Report on Foreign Trade Barriers, which invariably comes down hard on anything that impedes market access to American firms, actually ends up exonerating India on this score, as the following excerpt shows:

'Both state-owned and private Indian firms engage in most kinds of anti-competitive practices with little or no fear of reaction from government overseers or action from a clogged court system. India suffers from a slow bureaucracy and regulatory bodies that reportedly apply monopoly and fair trade regulations selectively. These practices are not viewed as major hindrances to the sale of US products and services at this time, although US industry (e.g. soda ash) has been denied access to the Indian market as a result of an adverse ruling by the government of India's monopolistic and restrictive trade practices commission." (2001 Report, p.187, emphasis added. This was reproduced in the 2002 Report as well.)

The USTR was thus concerned more about market access barriers created by India's competition authorities, rather than the RBPs that they were supposed to control. The MRTP ruling referred to in the last sentence was set aside in 2002 by the Supreme Court, as I discuss in greater

\footnotetext{
${ }^{7}$ In GATS, Members have listed ('scheduled') specific services which they have agreed to open up to foreign service providers.
} 
detail below. The USTR's 2003 Report welcomed this, but retained the complaint about India's "slow" and "selective" regulatory bodies, and also the exoneration of firms' RBPs as barriers to market access.

\subsection{Preventing abuse of anti-dumping procedures}

A third pillar also concerns denial of market access, but by government rather than private measures. This concerns the abuse of anti-dumping procedures. 'Dumping' is selling exports below 'fair' or 'normal' value, which is defined as the price realised by the exporter on domestic sales in his own market, a third market, or as a constructed measure of costs. The Uruguay Round Agreement on Anti-dumping allows imposition of anti-dumping duties on imported goods if a Member can establish that they are being dumped and are causing injury to its domestic producers. As an alternative, the Agreement allows a price undertaking, whereby the exporter agrees to refrain from reducing price below a certain minimum. However, there are many loopholes in the agreement, so well-organised domestic lobbies can obtain anti-dumping relief on flimsy grounds, and protect themselves from import competition. Anti-dumping duties usually nullify or even reverse the tariff concessions that Members have made in the WTO negotiations, while price undertakings in effect enforce an RBP: indirectly, by encouraging collusive price-fixing between the foreign and domestic firms, and directly, by forcing the former to refrain from price-cutting.

Application of competition policy principles governing predatory pricing, it was argued, would result in much stricter standards and prevent such abuse. Predatory pricing is pricing below costs with the specific intention of driving out rivals and establishing a monopoly. An antitrust investigation usually involves comparison of the alleged predator's price with its average variable costs (AVC). In contrast, when cost comparisons are used in anti-dumping petitions, the domestic industry only needs to demonstrate that the foreign firm is pricing below AVC plus general administration and sales costs and its usual profit margin. This means that establishing predatory pricing requires the foreign firm's price to be considerably lower than one that can trigger an antidumping duty. Further, unlike in a dumping case, it must be established that domestic firms are not merely being injured by these low prices, but that they are likely to close down and no other firm is likely to take their place. Only then can the alleged predator establish a monopoly position that would enable it to recover the profits it has sacrificed by charging artificially low prices. In other 
words, in contrast to anti-dumping mechanisms, laws against predatory pricing are designed to protect competition, not competitors. In a world market where there are several potential suppliers for most goods, it would be very difficult to prove that a foreign firm would be able to establish a monopoly, and predatory pricing in international trade is unlikely. Finally, even if it is found to occur, the antitrust remedy for predatory pricing is an injunction and a fine, which does not have the anti-competitive consequences of price undertakings or anti-dumping duties.

Replacing lax dumping rules with stringent rules on predatory pricing would therefore prevent governments from abusing the former to protect their industries from vigorous foreign competition. This argument sounds convincing to most economists, and similar views were put forward in the early discussions of the WGTCP, but practice has gone in exactly the opposite direction. In 2000, the Dispute Settlement Body adopted a decision (United States - Antidumping Act of 1916) according to which anti-dumping procedures were the only way in which Members could deal with predatory pricing by foreign exporters. Also, both the EU and US, who until recently were the most active users of anti-dumping, were strongly opposed from the earliest WGTCP discussions to applying predatory pricing principles. ${ }^{8}$

Ironically, in the last few years, many developing countries have emerged as the leading (ab)users of anti-dumping, so now there is even less enthusiasm for this move. Although India was one of the most vociferous critics of the way in which the developed countries were using antidumping, ${ }^{9}$ in the last two years it has itself imposed the largest number of anti-dumping measures. Evidence of how generously India is interpreting the anti-dumping rules comes from the 2002-03 Annual Report of the Directorate General of Anti-dumping and Allied Duties (DGAAD) of the Ministry of Commerce. Out of the 141 cases, covering the period 1992-2003, for which findings were tabulated in this report, three cases were withdrawn, and two were closed for lack of evidence. Of the remainder, it is striking that dumping was found in each and every case. Of these, antidumping measures were imposed in all but two cases. Thus, Indian industries seeking anti-dumping relief from low-priced imports had an almost 95\% chance of success, which is much higher than the success rate of petitioners in the developed countries which have been castigated for misusing anti-

\footnotetext{
${ }^{8}$ See the minutes of the Working Group meeting of July 1998, WT/WGTCP/M/5, paragraphs 38, 48 and 49.

${ }^{9}$ WTO document WT/WGTCP/W/111 (Communication from India, September 1998).
} 
dumping.

A perusal of individual case reports shows that in several cases, the DGAAD has accepted an increase in the foreign firms' market share (which was only to be expected in a period of trade liberalization) as evidence of injury, even though the Indian industry's sales and profits were increasing at the same time. Anti-dumping duties or price undertakings were imposed so as to ensure a 'non-injurious' import price which would guarantee a 'reasonable' rate of return to the domestic producers, based on their own cost data. This provided a cushion for inefficiency. A recent study applies statistical filters similar to those used in studies of anti-dumping in the EU and US to determine how many Indian cases could have been justified as legitimate responses to predatory dumping. It finds that only five of 92 Indian cases passed the test. ${ }^{10}$ In almost all cases, therefore, anti-dumping remedies have been used to protect Indian industries, and not to preserve competition. Even though employees and shareholders of these industries have benefited, anti-dumping measures have inflicted higher import costs on user industries, as it is mainly intermediate goods industries in the chemicals sector that have succeeded in obtaining protection. The latter are almost always highly concentrated and capital-intensive, while production in many of the user industries is predominantly in small-scale, relatively labour-intensive units which are being increasingly exposed to import competition. The Indian anti-dumping regime is therefore likely to have harmed rather than promoted competition and employment in the aggregate. But with both developed and developing countries now playing the same game, reform of anti-dumping seems to be off the WTO agenda for the time being.

\subsection{Preventing abuse of intellectual property rights}

A fourth area of concern in the early years of debate at the WGTCP was the abuse of intellectual property rights (IPRs). In granting what is in effect a legal monopoly to the right holder, these can cause an abridgement of competition for the sake of promoting innovation. Thanks to the Uruguay Round Agreement on Trade-Related Aspects of Intellectual Property (TRIPS), which has

\footnotetext{
${ }^{10}$ Samir K. Singh, An Analysis of Antidumping Cases in India, Unpublished M.Phil. dissertation, Department of Economics, University of Delhi, 2003.
} 
extended the coverage and duration of IPR protection, the trade-off has tilted decisively in favour of IPR holders, the vast majority of whom are resident in developed countries. Apart from the monopoly granted to the right holder, competition concerns arise in respect of restrictive conditions imposed when the patented technology or product is licensed to others. These conditions often restrict the licensee's pricing of the product, marketing it outside a designated area, and sub-licensing of the patent. There has been an increasing tendency for large corporations to cross-license their patents to each other with such conditions, effectively creating cartel-type arrangements without an explicit cartel agreement. Other competition-restricting clauses in patent licences include conditions requiring the licensee to purchase an input only from the patent holder, not to deal in rivals' products, or to 'grant back' any improvements in the patented technology or product exclusively to the original right holder.

Developing countries were especially concerned about what enhanced patent protection would entail for their access to essential drugs and seeds, which are sectors in which innovation is highly concentrated in a few large multinational corporations, and in which large mega-mergers occurred in the 1990s, further reducing competition. Developing countries were also concerned about the protection of their traditional knowledge (for example, the use of medicinal herbs) from 'biopiracy', or theft by multinational corporations with the technical, financial and legal resources to identify the scientific properties of this knowledge, codify it in patentable form, and then obtain patents. This debate, of course, went much beyond trade and competition policy, but did not go very far at the WGTCP. The competition safeguards built into the TRIPS Agreement (to be discussed below) were debated, but no consensus could emerge on whether further measures should be adopted. Developed countries, notably the United States, were against any dilution of their IPRs, and in any case recent antitrust thinking even within the US has inclined towards recognizing the dynamic benefits of strong intellectual property protection. The battle shifted to the TRIPS agreement, and thanks to pressure from some influential NGOs in developed countries, an agreement was reached on the eve of the Cancun Ministerial in 2003, allowing governments in developing countries, in cases of public health emergency, to license the production of essential patented drugs to manufacturers in other developing countries which had the capacity to manufacture them. However, developing countries are still open to abuse of IPRs in other products. 


\subsection{Cross-border cartels}

A fifth and much more widely acceptable argument for a MAC is based on the growing recognition of the cross-border effect of RBPs, especially cartels. Most countries assert the jurisdiction of their competition laws even if firms and their practices are located abroad, as long as they have adverse effects in the domestic market. This is known as the "effects doctrine". However, such extraterritorial application of national competition laws is difficult, especially in developing countries where such laws and their domestic enforcement are weak or non-existent. Even if national laws are applicable to foreign conduct on the basis of the effects doctrine, international cooperation is required for carrying out investigations in foreign countries.

International cartels, in particular, have generated much concern on this score. During the 1990s, competition authorities in the US and EU successfully prosecuted over forty international cartels that involved firms from more than one country. Multi-million dollar/euro fines were imposed, but only for the damage these cartels had caused to consumers in the US/EU, although there were indications that the cartels had also operated in other countries, including developing countries. The most widely cited cartels were those producing vitamins, steel tubes, and graphite electrodes. Proponents of a MAC have highlighted the huge costs, running into billions of dollars, inflicted on developing countries by such cartels, and held out the promise of cooperation in investigations. A related issue is cartelization in maritime transport, which is beyond the jurisdiction of national competition agencies. A few dominant private carriers have organized themselves into agreements known as liner conferences and fixed their charges collusively. According to one estimate, breaking up these shipping cartels could reduce transport prices by 20 percent on U.S. routes alone, enabling developing countries to save more than $\$ 2$ billion on their trade with the US. ${ }^{11}$ In view of the fact that in recent years cartels were the only specific antitrust issue debated at the WTO, giving rise to a large volume of literature, I critically examine this issue in detail in Section 5 below.

${ }^{11}$ C. Fink, A. Mattoo, and I. C. Neagu. 2001. 'Trade in International Maritime Services: How Much Does Policy Matter?" World Bank EconomicReview 16: 81-108. 


\subsection{Developments of the last few years}

As mentioned above, WGTCP discussions during the first few years of its existence were diffused and non-converging. Faced with a lack of consensus on so many issues, the Doha Declaration of the 2001 Ministerial Conference of the WTO limited further discussion at the WGTCP to the issue of hard-core cartels; application of the fundamental WTO principles of nondiscrimination, transparency and procedural fairness in competition policy; capacity building in developing countries; and voluntary cooperation between Members. (The relevant paragraphs are reproduced at Annexe B.) The EU modified its position to press for a MAC that would require Members to enact and enforce (possibly on a regional basis) a national competition law incorporating the fundamental principles. Such a law should at least prohibit hard core cartels, which were to be clearly defined, with any exemptions being well-defined and transparent. Countries would have to provide deterrent sanctions in their domestic competition regimes, and take on obligations that would be subject to the WTO dispute settlement mechanism, but these would be limited to the de jure consistency of their laws and regulations with the agreed framework. De facto implementation of these laws in practice, or the outcome of specific cases, would not be subject to review, according to the modified EU position. Transitional periods and technical assistance were offered for developing countries to enable them to comply with the proposed agreement. ${ }^{12}$ Underlying the position of the EU and most developed countries was the presumption that vigorous competition is undeniably a good thing, and that government policy should be geared towards promoting it.

While acknowledging the harm caused by international cartels, India and many other developing countries emphasized the need to respect their diversity in terms of stages of development, socio-economic circumstances, legal frameworks, and cultural norms. They opposed a "one size fits all" agreement, and drew attention to the dangers of transplanting a competition policy framework that has evolved over many years in industrial countries into economies lacking in experience, expertise, and institutional memory. Several developing countries claimed that development required giving greater priority to policy objectives other than promotion of competition, and questioned virtually every specific proposal advanced by the proponents, including

\footnotetext{
${ }^{12}$ WTO documents WT/WGTCP/W/193 and W/222 (Communications from the European Community and its Member States, 2002).
} 
the necessity of applying the fundamental WTO principles of non-discrimination, transparency and procedural fairness to competition policy. While they acknowledged the importance of transparency and procedural fairness, they raised concerns about the financial and administrative burdens they would have to incur in implementing an agreement which enshrined developed-country standards. I deal with the debate on non-discrimination in detail below. As regards cooperation, developing countries were concerned about whether their investigators would receive meaningful assistance and information from authorities in developed countries, given that the proposed framework envisaged only 'voluntary' cooperation. They were also concerned that their own agencies, with scanty resources, would be deluged with requests for cooperation from other countries.

In general, lacking resources and experience in competition policy, developing countries were reluctant to be subjected to WTO dispute settlement, which would leave them vulnerable to trade sanctions in case they failed to comply with multilateral commitments in this area. Underlying their position was an aversion to taking on any new WTO commitments, especially in an area in which most of them had little experience, given their experience with earlier (Uruguay Round) agreements in which the promised benefits did not materialize, and/or the costs of compliance proved too onerous. Some of them, including India, questioned the virtues of unrestricted competition itself, and did not want to surrender the 'policy space' for implementing industrial policies geared to the promotion of 'national champions' through restrictions on competition. I undertake a more detailed analysis of three of the key disputed issues (national treatment, industrial policy, and hard core cartels) in Section 5 below.

Given such irreconcilable differences between the proponents and the opponents of a MAC, in the last couple of years of the WGTCP's discussions, some developed and developing countries suggested an alternative in the form of an agreement with non-binding provisions, allowing for technical assistance and constructive 'peer review' rather than adversarial dispute settlement. Other developing countries remained unconvinced, apprehensive of asymmetric 'peer pressure' that would force them to conform to developed countries' ideas on competition policy, while the latter countries would be immune to such pressure coming from poor countries. They were sceptical of adequate assistance and cooperation coming their way. They viewed the substantial costs of a review process as an unnecessary burden that they could easily do without, and were concerned about the loss of 
flexibility in pursuing developmental objectives and their limited capacity to enforce competition laws. There was no clear indication regarding the nature of peer review - mandatory or on-demand. Further, the review criteria remain unresolved, with the EU and Australia emphasizing the inclusion of core principles and developing countries strongly opposing any such move. There was little discussion on frequency of reviews, appointment of examiners, members of peer group and the question of approval of reports. These discussions remained inconclusive, but the peer review approach may yet be adopted in a non-WTO framework, as it has in the OECD.

As late as February 2003, the EU was continuing to insist that according to the Doha declaration negotiations on all the four Singapore issues 'will commence after Cancun", and that they "are a key element of the DDA [Doha Development Agenda] and part and parcel of the Single Undertaking". Only clarification of modalities of the negotiations remained to be worked out. However, some new signs of flexibility were apparent. The EU also held open the possibility that the discussion on modalities on a MAC could include exemptions from the 'core' principle of nondiscrimination; differential levels of commitment and implementation periods for developing countries; and even "how and in what timeframe (or even whether) WTO Members or certain categories of WTO Members would assume some or all of the obligations resulting from these agreements". 13

This newly conciliatory position could well have been a ploy to induce wavering developing countries to agree to the commencement of negotiations, with the EU hardening its stance once they were under way. But ultimately, the developing countries' opposition to any negotiations towards a MAC, along with disputes over agriculture and the other Singapore issues, came to a head in September 2003 at the Cancun Ministerial, which ended with no consensus. On the eve of the Ministerial, several developing countries, led by India, formally protested that their views on the Singapore Issues had been bypassed in consultations and had not been reflected in the draft of the Ministerial declaration. ${ }^{14}$ Their statement listed several points which they felt had not been

\footnotetext{
${ }^{13}$ These quotations are from 'Singapore Issues - The Question of Modalities" (Communication from the European Communities), WTO document WT/GC/W/491, 27 February 2003.

${ }^{14}$ See the statement by 16 developing countries (with Bangladesh signing on behalf of the least developed countries) on the eve of the Cancun Ministerial (WT/MIN(03)/W/4). The excerpts pertaining to competition policy are reproduced as Annexure C.
} 
adequately addressed and required further clarification in the Working Group. Most of these are discussed at various points in this monograph. At Cancun itself, the EU showed a willingness to unbundle the Singapore Issues and drop competition policy from the agenda, but subsequently it continued to raise the possibility of introducing it in some other form. In the Framework Agreement that was reached in July 2004, the WTO General Council formally dropped three of the four Singapore Issues, including competition policy, from the Doha work programme altogether, ${ }^{15}$ but the debate is likely to continue outside the WTO, and competition policy may well be reintroduced in the WTO after completion of the Doha round. Policymakers and the emerging "competition community" in India should therefore remain engaged with the issues. This process should also contribute to improving the effectiveness of the new Competition Act, which as I shall discuss in Section 4, has several clauses that could create problems in its enforcement.

\subsection{Conclusion: Assessment of the WTO debate}

It now appears that there will be no MAC at the WTO for the foreseeable future. What did this lengthy debate within and outside the WTO achieve? Developing countries could make no headway on the competition concerns that were most relevant to them, such as the cross-border consequences of mega-mergers and the abuse of anti-dumping procedures and intellectual property rights. The consensus on cartels, as I shall show below, amounts to very little without agreement on information sharing and enforcement assistance. For the proponents of a MAC, although their efforts seem to have ended in failure, the prominence given to this issue during the debate has enabled the EU to attain its major objectives even without an agreement. More than fifty developing countries have adopted competition legislation in the last decade, with most of them prohibiting hard core cartels and providing explicitly or implicitly for non-discrimination. India's new Competition Act is no exception, as I shall show below. Also, for the seven years that the issue was discussed at the WTO, the developing countries were forced to devote a considerable part of their limited resources and expertise to understanding the implications of unfamiliar issues like competition policy and its relationship to international trade. While this might have been a valuable learning experience that

\footnotetext{
${ }^{15}$ WTO document WT/L/579. Trade facilitation was the only Singapore Issue that was kept on the table. The relevant excerpt from the Agreement is reproduced as Annexure D below.
} 
could contribute to domestic competition policies regardless of a MAC, as it has to a certain extent in India, it did force these countries to divert their resources away from other WTO issues. Also, part of the price that developing countries paid for getting three of the four Singapore issues off the agenda could well have been concessions they seem to have made at Geneva in respect of agricultural and non-agricultural market access.

\section{International agreements concerned with competition policy}

\subsection{Bilateral, multilateral and regional agreements}

In the absence of a WTO MAC, international agreements relating to competition policy take the form of bilateral, regional, or sectoral arrangements, which have been expanding in recent years. The earliest bilateral agreement was between the EU and the US, adopting a policy of 'positive comity' in investigating each other's complaints. This requires competition policy authorities to consider, taking into account their own laws, procedures, interests and resources, complaints against anti-competitive conduct by firms in their jurisdiction which adversely affect parties in the other jurisdiction. This does not oblige the authorities to initiate prosecutions, and excludes mergers and also export cartels (which are exempted from competition laws in both jurisdictions). Even otherwise, EU and US authorities frequently coordinate their enforcement activities.

Several countries, led by the EU and US are also individually entering into bilateral (or, in the case of Australia, Canada and New Zealand, trilateral) agreements with each other. These agreements usually require traditional ('negative') comity: each party undertakes to notify the other when it is proposing to enforce its competition laws in a way that might affect the latter's important interests (for example, investigating a person or practice located in each other's territory), and to take their views into account. This approach has been encouraged by a 1995 Recommendation on Cooperation between Member Countries on Anti-competitive Practices Affecting International Trade issued by the Organization for Economic Cooperation and Development (OECD), which comprises all developed countries and more recently three developing countries (Korea, Mexico and Turkey). Some of these agreements also provide for assistance and coordination in enforcement and in obtaining information, subject to local laws, and for notifying each other in case RBPs under investigation in their territories might have an adverse effect in the other signatory's territory. These 
additional elements have not been included in the only bilateral agreement between a developed and a developing country, that is between the US and Brazil, which otherwise contains elements of both positive and negative comity. In the US and some other countries, certain competition law violations are criminal offences, and the US and Canada have a Mutual Legal Assistance Treaty, which commit them to assist in criminal investigations, by executing search warrants for obtaining evidence. They also reached a positive comity agreement as recently as October 2004. A 2001 agreement between Denmark, Iceland and Norway goes much further in providing for assistance in investigation of parties located in each other's jurisdiction, and for supply of confidential information.

Another major OECD competition policy document, dealing with one specific antitrust area, is the 1998 Recommendation on Hard Core Cartels. This called upon members to take action against them, and to cooperate with each other by sharing documents and information, and gathering evidence on request. However, such cooperation was to be voluntary, "consistent with a requested country's laws, regulations, and important interests". It could be declined on the grounds that the request was not thus consistent, "or on any other grounds, including its competition authority's resource constraints or the absence of a mutual interest in the investigation or proceeding in question". The definition of such cartels specifically excluded any arrangements that reasonably related to cost-reducing or output-enhancing efficiencies, those that were excluded from the coverage of a member country's own laws, or authorised in accordance with those laws. The Recommendation also encouraged members to enter into bilateral or multilateral agreements in order to overcome obstacles in the enforcement of their laws against hard core cartels, and invited non-member countries to associate themselves with the Recommendation and implement it. As I shall point out below, a recent official review has expressed disappointment over the lack of progress on implementing the Recommendation.

Provisions related to competition policy also figure in several regional trade agreements, notably the EU, the North American Free Trade Agreement (NAFTA), the Andean Common Market (ANCOM), the South American Common Market (MERCOSUR), the Common Market for Eastern and Southern Africa (COMESA), the Southern African Development Community (SADC), and the Caribbean Common Market (CARICOM). The subject is also included in the protracted discussions towards a Free Trade Area of the Americas (FTAA). The 1998 Panama communiqué signed by the United States, Canada, and nine developing countries in the Western Hemisphere affirms their 
intention to cooperate in dealing with cartels and to develop competition regimes in the smaller members. The process has gone furthest in the EU, which enforces a common competition policy with respect to RBPs involving more than one member state, and also regulates mergers above a certain threshold. Directorate-General IV of the European Commission functions as a supra-national competition authority for this purpose, cooperating with national agencies in the member states, with whom it can exchange confidential information. All countries applying for EU membership, and also those with whom the EU has free trade agreements, are required to apply EU competition principles to trade with the EU. Recently, CARICOM and MERCOSUR have begun moving in the direction of agreeing on common norms and centralised enforcement. Most of the other regional agreements merely declare the parties' commitment to implement measures to regulate RBPs, especially those affecting trade between them, and provide a framework for consultations.

Beyond all these formal agreements, with their varying levels of obligations and enforceability, informal cooperation between national competition authorities is slowly growing. This usually involves discussing the broad contours of a case (such as market definition, possible anti-competitive effects, and remedies), and sharing non-confidential information. Experience shows that successful cooperation requires that the authorities have adequate resources to address each other's requests, share common norms regarding competition policy and similar skill levels, and that resolving the case is in their mutual interests. Once a certain degree of trust is developed, confidential information can be shared subject to safeguards. As yet, such cooperation is well advanced only between a handful of developed countries, although developing countries such as Brazil and Korea have obtained very limited help from US competition agencies in their attempts to prosecute international cartels. There seems to be no prospect for the harmonization of national competition laws, much less a supra-national competition agency. However, continuing interaction between competition authorities, both bilaterally and at the various international forums discussed in this section, could eventually promote some convergence between them. Section 6 will discuss what direction this could take.

\subsection{The UNCTAD Set}

At least in principle, one of the most relevant competition agreements from the point of view of developing countries, in view of their participation as well as its explicit development focus, is 
the UNCTAD 'Set of Multilaterally Agreed Equitable Principles and Rules for the Control of Restrictive Business Practices" (known as the UNCTAD Set). The Set was unanimously adopted by the United Nations General Assembly in 1980, and its validity has been reaffirmed at U.N. review conferences every five years thereafter. In that sense, it has greater coverage than any of the agreements discussed above, or indeed the WTO, as U.N. membership greatly exceeds that of the latter. Its scope is also quite comprehensive: according to Section B(ii), it is supposed to apply to all countries, and to all transactions in goods and services by all enterprises. (It is not applicable to intergovernmental agreements, or RBPs directly caused by such agreements, or intra-firm transactions).

Many of the issues discussed in the WTO Working Group twenty years later were already mentioned in the Set. For example, the "General Principles" set out in Section C(i) call for bilateral and multilateral consultation, collaboration, and exchange of information between governments to facilitate the control of RBPs. Section C(iii) calls for preferential or differential treatment for developing countries, particularly in promoting the establishment or development of their domestic industries, and regional or global arrangements between developing countries. Various sections require states, particularly developed countries, in controlling RBPs, to take into account the needs of developing countries. Section D consists of a list of do's and don'ts for enterprises, including multinational corporations, such as conforming to national laws concerning RBPs, cooperating with national competition authorities, and refraining from certain specific practices when they would have adverse effects on international trade, particularly on developing countries. These listed practices are the standard RBPs and abuses of dominance that are dealt with in the competition laws of most countries. Section E establishes principles for the governments of member states. These include the principles of non-discrimination, transparency, procedural fairness, and protection of commercial secrecy, as well as mechanisms for exchange of information, mutual assistance, and technical support to countries with little experience. Section F, on international measures, calls for the development of common approaches, pooling and dissemination of information on national legislation and experiences under the auspices of UNCTAD, and for consultations between states on control of RBPs. It also calls for UNCTAD to facilitate technical assistance, advisory and training programmes, especially for developing countries. Section G sets up an Intergovernmental Group of Experts (IGE) to provide a forum for multilateral consultations, and to undertake research studies 
and submit reports and recommendations for modification of the Set.

From this brief overview, it is clear that the Set provides only a very general framework. Most importantly, it is non-binding on the member states of the U.N. All its provisions only call upon enterprises and states to behave in certain ways, with no forum for enforcement or dispute settlement. (Para G.4 explicitly prevents the IGE from acting as a tribunal to pass judgement on the conduct of individual governments or enterprises.) Calling upon multinational firms to refrain from RBPs, or developed country governments to take into account the interests of developing countries amounts to mere exhortation. The fact that many of the same basic issues and principles were debated more than twenty years later in the WTO Working Group shows how limited the effect of the Set has been. No doubt, annual meetings of the IGE, and quinquennial conferences to review the Set (most recently in 2000), have helped developing countries to exchange experiences and gain familiarity with competition issues.

\subsection{WTO agreements}

Within the framework of the WTO, competition policy figures implicitly in the GATT and explicitly in three Uruguay Round Agreements. ${ }^{16}$ Article III of the GATT concerns National Treatment (NT), or non-discrimination between domestic and foreign goods in Members' domestic taxes and regulations. The justification for NT is that concessions made by Members in respect of reduced trade barriers ('border measures"), the raison d'etre of the GATT, could easily be undone if they could impose "behind the border" internal taxes and regulations that discriminate against foreign goods. According to Section 4 of this Article, "The products of the territory of any contracting party imported into the territory of any other contracting party shall be accorded treatment no less favourable than that accorded to like products of national origin in respect of all laws, regulations and requirements affecting their internal sale, offering for sale, purchase, transportation, distribution or use." In the 1997 Kodak-Fuji dispute, as noted above, a DSP did bring

\footnotetext{
${ }^{16}$ I am following the usual practice of treating the "WTO framework" as comprising the entire package of Agreements, including the modified GATT, Understandings and Protocols, that were entered into at the creation of the WTO in 1994 and subsequently, as well as the evolving jurisprudence of its Dispute Settlement Body.
} 
Japan's competition laws and guidelines under scrutiny under this section. Although the panel exonerated Japan of violating NT, this did establish a clear precedent, extending NT to competition policy.

Three existing WTO agreements contain explicit provisions on competition policy. The weakest is a modification of Article XIX of the GATT and the Uruguay Round Agreement on Safeguards, which permit Members to impose import restrictions in case of significant increases in imports that threaten injury to a domestic industry, provided they compensate the exporting country. Paragraph 22 of the latter Agreement prohibits restrictions falling outside that framework, specifically measures such as voluntary export restraints and orderly marketing arrangements that many developed countries abused during the 1970s and 1980s. Competition policy is brought in by paragraph 24, which requires that 'Members shall not encourage or support the adoption or maintenance by public and private enterprises of non-governmental measures equivalent to those referred to in paragraph 22 above." This reinforces the agreement to phase out all such measures by which trade was restricted by nominally private RBPs but at official behest.

Various provisions of the General Agreement on Trade in Services (GATS) are more specifically related to competition policy. Article VIII requires that each Member ensure that any service supplier to which it has granted a monopoly should not act in a manner that would infringe the Member's specific GATS commitments, or abuse its power in areas outside the scope of legal monopoly. Article IX, which deals with restrictive business practices, requires Members to enter into consultations at the request of any other Member with a view to eliminating such practices. However, it requires only "full and sympathetic consideration" of requests for consultations, and supply of "publicly available non-confidential information". Article XVII requires National Treatment, which in GATT was limited to goods, to be applied to "services and service providers of any other Member". This extension of NT from foreign goods to foreign firms would be a precedent for any MAC, which is primarily concerned with the behaviour of firms. However, Article XVII does permit Members to set out "conditions and qualifications" on NT for its scheduled sectors. Once entered, these and other commitments can only be modified by suitably compensating any other Member who is adversely affected by the modification. 
Special GATS rules were deemed to be necessary for the telecommunications sector, where a major issue is the abuse of dominant positions by existing suppliers, often in the public sector or legally sanctioned private monopolies, to block the entry of new competitors. Because it is costly and wasteful for each supplier to install its own wire network, one way in which an incumbent can block competition is to deny new entrants access (interconnection) to its pre-existing network. The Annex on Telecommunications requires Members to provide service suppliers of other Members with access to their telecommunications networks. A later WTO Reference Paper goes further in requiring Members to implement "appropriate measures" to prevent major suppliers "from engaging in or continuing anti-competitive practices" in this sector. It also requires that signatories ensure that these suppliers provide interconnection on non-discriminatory terms. Unlike the other WTO agreements, which are binding on all Members, these telecom-related agreements were signed only by some Members.

The other WTO agreement with specific competition policy clauses is the TRIPS agreement protecting intellectual property rights (IPRs). Article 31 lays down conditions under which governments may allow compulsory licensing of a patent, that is, its use by parties other than the owner on payment of reasonable royalties to the latter. Among these conditions are that the proposed user should have tried unsuccessfully to obtain a normal commercial license from the owner, should use the compulsory license primarily for supplying the domestic market of the Member granting the license, and should pay "adequate remuneration" to the right holder. The first two conditions are waived by Article $31(\mathrm{k})$ in cases where the use of the patent is permitted "to remedy a practice determined by judicial or administrative process to be anti-competitive". Article 31(k) also weakens the third condition, stating that "The need to correct anti-competitive practices may be taken into account in determining the amount of remuneration in such cases".

The use of intellectual property is, of course, usually licensed voluntarily by the right owner on commercial terms. Article 40 of the TRIPS Agreement relates to anti-competitive practices in such contractual licences, some of which were described in Section 2.4 above. It allows Members to regulate, through their national legislation, licensing practices or conditions that abuse IPRs in having an adverse effect on competition. It also requires Members to accord 'full and sympathetic 
consideration" to requests for consultations and to provide publicly available non-confidential information, if a Member suspects that its laws in this area are being violated by an IPR owner based in another's territory. Thus, it is merely a permissive section, which leaves the burden of combating anti-competitive licensing practices on the Members' domestic authorities. Most developing countries would not have the technical or legal expertise to mount effective challenges to such practices.

The WTO, as is well known, has a powerful dispute-settlement mechanism to enforce the agreements. However, as the WTO agreements are between Member governments, the obligations they entail are imposed on the governments, rather than firms who might be guilty of RBPs. As yet, the only complaint that has been settled against a Member involving competition policy has been the 2004 Telmex case mentioned above, in which a Dispute Settlement Panel held that the Reference Paper on telecommunications required Mexico to take action against a cartel of its telecommunications firms. There has been no jurisprudence on the competition-related aspects of the TRIPS Agreement.

\section{Recent changes in Indian competition policy in relation to the international debate}

India is in transition from its old competition law, the 1969 Monopolies and Restrictive Trade Practices Act, to the new Competition Act of 2002. ${ }^{17}$ The MRTP Act originally covered monopolistic and restrictive trade practices, as well as concentration of economic power. Its intention was not just the promotion of competition, but also "public interest" considerations such as protecting employment as well as control of the concentration of economic power in large business houses or dominant firms. A substantial amendment to the MRTP Act in 1984 introduced new sections dealing with Unfair Trade Practices, such as misleading advertising and prize schemes. The sections concerning concentration of economic power (which regulated expansion, setting up of new units, and mergers and acquisitions) were deleted by the sweeping amendment of 1991 at the outset of the economic reforms, because it was believed that they had become counterproductive and were preventing the growth of Indian firms so as to reap economies of scale. Merger review has been reintroduced, for firms above a certain threshold, in the new Competition Act.

\footnotetext{
${ }^{17}$ At the time this monograph was last revised (early November 2004), the substantive provisions of the Competition Act had not yet been brought into force because of a pending case before the Supreme Court challenging the appointment of a civil servant as Chairperson of the proposed Competition Commission.
} 


\subsection{Positive features of the Competition Act}

The Competition Act improves upon its predecessor in many ways. It defines crucial terms that were left undefined in the MRTPA, for example cartel, consumer, predatory pricing and turnover. Several criteria have been listed for defining the 'relevant market' and the 'relevant product' in determining effects of business conduct on competition. The Competition Act provides

for regional benches of the proposed Competition Commission, as well as specialized merger benches, unlike the MRTP Commission, which sat only in Delhi. Unlike the MRTPA, the new Act provides for outside advisers and consultants, and for hearing expert testimony. Firms violating the new law can be fined ten per cent of their turnover, whereas the MRTP Commission could only issue 'cease and desist' orders, with modest fines for not complying with them. Apart from regulatory and adjudicatory functions, the Competition Commission, unlike its predecessor, is also entrusted with 'competition advocacy'. The Competition Act also includes clauses specifically related to crossborder competition issues that are the focus of this monograph; these are discussed in greater detail below. All these are of course only enabling provisions; whether and how they are implemented remains to be seen.

Another range of improvements relates to what the Act does not attempt to cover. It wisely avoids unfair trade practices (UTPs). The vast majority of cases before the MRTP Commission in recent years came under the chapter on UTPs and the section on compensation. These involved mainly complaints relating to misleading advertising, deficiency in quality of goods or delayed delivery, usually of flats or cars booked with dealers. Matters such as these should have been taken up by the consumer forums under the Consumer Protection Act (COPRA), because adjudicating consumer cases requires principles that are quite different from those required for a modern competition law. Consequently, the limited resources of the MRTP Commission were unnecessarily diverted away from the monopolistic and restrictive trade practices that were its original responsibility. The Competition Act rightly transfers pending UTP cases to the National Commission constituted under COPRA, to be disposed of under its provisions, which have recently been streamlined. 
In recent years the Commission has also entertained several complaints under clause 2(o)(ii) of the subsection defining Restrictive Trade Practices (RTPs), which refers to "manipulation of prices ... so as to impose on the consumers unjustified costs or restrictions". This issue is related to the second way in which the Competition Act represents an important improvement, again because of what it does not include. The MRTPA was pervaded by the notion that the "public interest"was to be decisive in adjudicating cases. This criterion has been removed from the Competition Commission's mandate in the new Act. As I have shown in several earlier papers, ${ }^{18}$ this unexceptionable principle was interpreted in various ways by different benches of the MRTP Commission. Their interpretations usually had nothing to do with maintaining competition, but were based instead on idiosyncratic notions of social justice, such as protecting employment in industries threatened by low-priced imports, or (in conjunction with the "price manipulation" aspect of alleged RTPs) protecting consumers from prices which the Commission believed to be excessive. Evidence of collusion, market dominance or effects on competition, which should be central to establishing an anti-competitive act, was not required. The MRTP Commission thus displayed a tendency to issue orders against prices that it regarded as 'unfair', whether too high or too low. However, what is fair to the seller will generally be unfair to the buyer or to other sellers. The proper role for a competition authority, as rightly enunciated by the Supreme Court in setting most of these orders aside, ${ }^{19}$ is to restrain business practices that endanger competition. Unemployment is a legitimate concern, but requires more sophisticated approach, as I indicate below.

\subsection{Treatment of cross-border issues}

Both the old and new laws have clauses dealing with some of the cross-border issues discussed above. Like the competition laws of most other countries, both exclude from their purview the actions of firms to the extent they relate exclusively to exports. Section 15 of the MRTP Act stated, in relevant part, that 'No order made under this Act with respect to any monopolistic or restrictive trade practice shall operate so as to restrict ... the right of any person to export goods from

\footnotetext{
${ }^{18}$ See my earlier published papers: "Predation, Protection and the 'Public Interest", Economic and Political Weekly, 2 December 2000, "Competition Policy: India and the WTO", Economic and Political Weekly, 22 December 2001'; and 'Trade, Investment and Competition Policy: An Indian Perspective", in A. Mattoo and R.M. Stern (eds.), India and the WTO (Oxford University Press, New York, 2003).

${ }^{19}$ For Supreme Court judgments on the proper interpretation of price manipulation, see Principal, Apeejay School vs MRTP Commission (2001) 8 SCC 702 and Rajasthan Housing Board vs Parvati Devi, (2000) 6 SCC 104. On low-priced imports, see Haridas Exports vs All India Float Glass Manufacturers' Association, (2002) 6 SCC 600.
} 
India, to the extent to which the monopolistic or restrictive trade practice relates exclusively to the production, supply, distribution or control of goods for such export." In the Competition Act, Section 3 (governing anti-competitive agreements) contains a subsection (5) which states, again in relevant part, that 'Nothing contained in this section shall restrict ...the right of any person to export goods from India to the extent to which the agreement relates exclusively to the production supply, distribution or control of goods or provision of services for such export". Although this exclusion is limited to anti-competitive agreements, an implicit exclusion also applies to Section 4 on abuse of a dominant position, because an Explanation attached to that Section clearly states that a "dominant position" is to be determined with respect to the relevant market in India. Similarly, according to Section 6(1), the anti-competitive effect of a combination (merger or acquisition) is to be considered with reference to "the relevant market in India".

The MRTP Act also contained Section 14, giving the MRTP Commission power to issue orders against firms which did not carry on business in India "with respect to that part of the practices which is carried on in India". This seemed to resemble the 'effects doctrine' of other jurisdictions. The MRTP Commission employed this in a number of cases, most recently in issuing injunctions against imports from a group of American soda ash producers (ANSAC) in 1996 (on grounds that they constituted a cartel) and from a group of Indonesian float glass producers in 1998 (on the grounds that they were engaged in predatory pricing) ${ }^{20}$ However, in a significant ruling in 2002 (the Haridas Exports case cited in the previous footnote), the Supreme Court held that the effects doctrine became applicable only if a restrictive trade practice took place after the goods had entered India, and only if it involved an Indian party. The Court held that the Commission could not regulate foreign prices, nor order restrictions on imports. This would have made it almost impossible for the Commission to take action against international cartels, whose activities have been given so much publicity in the international discussion. However, the government moved quickly to ensure that no similar problem arose with the Competition Bill, which was then pending in Parliament. It already contained (in Section 32) a much more explicit statement of the effects doctrine. After the Supreme Court judgment, the government amended the Bill, inserting a new section 33(2). This explicitly arms the Competition Commission with the power grant a temporary injunction restraining any party from importing goods, if the import is likely to contravene the substantive sections dealing

\footnotetext{
${ }^{20}$ See the papers listed in the previous footnote for details.
} 
with anti-competitive agreements, abuse of dominance, or mergers.

Although restoring the Indian competition authority's power to take action against foreign firms was certainly necessary, arming it with the power to restrict imports was not a sensible decision. Even if a prima facie case can be established, an import prohibition would not be appropriate. Imports might be targetted for being priced too high (e.g. by a foreign merger or cartel), or too low (by a dominant foreign firm engaged in predatory pricing). If the former, then countering a private anti-competitive practice with a further restriction of competition in the form of shutting out imports from the offending parties amounts to cutting off one's head to cure a headache. The threat of an import restriction might be useful for compelling foreign defendants to pay the fine if the case is decided against them, but to shut out their goods for the entire duration of the case is selfdefeating. The Supreme Court, in its Haridas Exports ruling, observed that the opposite party must always be given a hearing before an injunction is granted, but the new Section 33(2) explicitly dispenses with this requirement. As the two cases that were finally decided in Haridas illustrate, the injunction can remain in force for several years during the regular hearing, the review hearing, and the appeal to the Supreme Court. The exporters, the importers, and the ultimate consumers cannot be compensated for the losses they have suffered in the meanwhile. Requiring the posting of a bond or cash deposit (as in the case of provisional anti-dumping and countervailing duties), to be adjusted against the fine in case the verdict goes against the cartel and refunded otherwise, would be better than denying market access.

If, on the other hand, the impugned practice is predatory pricing, then an import restriction will probably be held to be inconsistent with Article VI of the GATT and the Uruguay Round Antidumping Agreement, which lay down a procedure for dealing with low-valued imports, and require domestic laws to be brought into conformity with that procedure. As noted in Section 2.3 above, in 2000 the WTO Dispute Settlement Body held that the United States 1916 Antidumping Act was inconsistent with these requirements, and could not be exempted on the grounds that it was a national competition law. Ironically, India included itself as a third party in that case, on the side of the complainants, the EU and Japan. The US can get away with defying such rulings (it has not yet amended the Act) but India is likely to be hit by retaliatory tariffs for similar violations. As the Supreme Court's Haridas verdict also pointed out, the appropriate remedy for low-priced imports 
is an anti-dumping duty. Unlike an import prohibition, this brings revenue to the government while maintaining some price discipline on domestic producers.

As I pointed out in Section 2.3, the Director General of Antidumping and Allied Duties in the Commerce Ministry recommends a duty in almost all cases brought to it. But petitions are usually initiated by highly concentrated and organized large scale industries, so this almost guaranteed protection for oligopolistic industries itself creates a competition policy issue which is being neglected. The provision in the Competition Act will provide yet another opportunity for large domestic producers with the resources to approach the Competition Commission to fend off competition from imports, with adverse consequences not only for consumers, but also for small enterprises that use the imported product as an input. As the latter are likely to operate in more competitive markets and also employ more labour than the large upstream suppliers who obtain the injunction, the overall effect on competition as well as employment are likely to be negative.

Aside from the question of import restrictions, there is a problem with the regulation of foreign mergers. Section 5 of the Competition Act, which deals with combinations, lays down asset and turnover thresholds for parties to a combination. If these thresholds are exceeded, the combination would be subject to review. The thresholds are defined separately for assets and turnover inside and outside India. This seems to suggest that mergers of foreign firms will also be subjected to review, although it is not clear how an injunction against such a merger can be enforced. At best, the Indian subsidiaries of the merging firms can be prevented from merging. But since they will be under the control of their merged foreign parent, they might engage in anti-competitive practices while remaining nominally separate and without entering into any agreement that would bring them under Section 3. A more feasible remedy would be to exploit Section 31(3) of the Act, which gives the Competition Commission the authority to propose modifications to any merger or acquisition referred to it. It can use this to permit the merger on condition that the firms license some patents, divest some brands and plants, or terminate some RBPs so as to safeguard competition. This has been done by competition authorities in much smaller developing countries even in cases involving powerful multinational corporations, for example by Pakistan in the merger of the local subsidiaries of Lipton and Brooke Bond and by Zambia and Zimbabwe in that involving Coca Cola and Cadbury-Schweppes. 
A clause that will be potentially useful in dealing with cross-border RBPs was inserted as Section 18, which empowers the CCI to "enter into any memorandum or arrangement with the prior approval of the Central government, with any agency of any foreign country". As we saw above, this is a growing trend amongst countries in their efforts to crack down on cross-border RBPs. However, such cooperation depends on similar levels of experience and expertise as between the participating agencies. The MRTP Commission did not have much of the relevant experience, as the criteria that it employed were not those of modern competition analysis. As we saw, public interest concerns other than competition were often decisive in guiding its decisions. The Competition Act contains much more modern criteria, but it will require a long period to build up the relevant expertise so as to engage foreign competition authorities on their own terms. Also, the MRTP Commission had a very poor record in prosecuting even domestic cartels, which involves investigative skills similar to those required in detecting any kind of conspiracy. The new Competition Commission will take a long time to develop the kind of track record that will make it an attractive partner for foreign competition agencies. As we shall see below, trust and cooperation between national competition agencies has taken a long time to evolve even in developed countries which have had much more in common, and there remain frictions even now.

\subsection{Cartels and exemptions}

As cartels were the post-Doha focus of the debate at the WTO, an examination of relevant provisions of the Act is appropriate. Interestingly, Section 3 contains what amounts to a per se prohibition of exactly the kind of 'hard core' cartels targeted by the EU (and more broadly, the OECD). Section 3(1) of the Act prohibits agreements that "cause an appreciable adverse effect on competition within India"; 3(2) holds such agreements to be void; and then 3(3) lists four specific types of agreement that shall be "presumed to have an appreciable adverse effect on competition". These are horizontal agreements (i.e. between rival sellers of similar products), involving pricefixing, output restriction, market sharing, or bid-rigging, that give rise to what are internationally known as "hard-core cartels". The more serious problem is in the related section 19(3), which reads as follows: 
"The Commission shall, while determining whether an agreement has an appreciable adverse effect on competition under section 3 , have due regard to all or any of the following factors, namely:

a) creation of barriers to new entrants in the market

b) driving existing competitors out of the market

c) foreclosure of competition by hindering entry into the market

d) accrual of benefits to consumers

e) improvements in production or distribution of goods or provision of services

f) promotion of technical, scientific and economic development by means of production or distribution of goods or provision of services."

First, it is unclear as to how criterion (c) is different from (a). Second, while criteria (a) to (c) help to determine whether an agreement inhibits competition, (d) to (f) invite the Commission to consider whether an anti-competitive agreement can be permitted on other grounds, and have nothing to do with the introductory sentence. These are two entirely separate considerations, and even the MRTP Act recognized them as such, defining restrictive trade practices (RTPs) in one section, listing specific anti-competitive agreements in another, and deeming these agreements to be "prejudicial to the public interest" unless they satisfied certain conditions (colloquially known as "gateways") in a third. Lumping competition and non-competition criteria together in one subsection betrays an important conceptual confusion in the Competition Act, and could create a serious problem in implementation.

These various provisions seem to be a mangled version of the two-pronged approach in Article 81 of the EU Treaty, which provides the legal foundation for antitrust policy in the EU in respect of anti-competitive agreements. Its section 81(1) lists five specific types of agreement that are prohibited, and then 81(3) permits exemptions for efficiency-enhancing agreements and concerted practices, provided that they allow consumers a fair share of the resulting benefits, do not impose restrictions that are unnecessary to the efficiency objective, and do not allow for substantial elimination of competition. All four of these conditions have to be satisfied for an exemption to be granted. (These lists are reproduced almost verbatim in Sections 2(2) and 9 of the UK Competition 
Act of 1998). In contrast, clauses 19(3)(d) to (f) of the Indian Competition Act are permissive rather than mandatory conditions.

Further confusion on this score was created by an amendment to Section 3(3) that was introduced when the Competition Bill was being passed. This amendment excluded efficiencyenhancing joint ventures from the four types of agreement deemed to be anti-competitive. Such an exemption is available in other countries also, but with crucial differences. A 'block exemption' has been available since the mid-1980s in the EU for joint ventures devoted to research and development, subject to certain conditions. In the US, the 1984 National Cooperative Research Act allowed such ventures to be treated under a rule of reason, allowing offsetting efficiency benefits to be considered, unlike other arrangements that restrict competition, which are generally treated as illegal per se. In contrast, the new exemption in the Indian Competition Act is too broad, in that it is neither limited to $\mathrm{R} \& \mathrm{D}$, nor imposes any other conditions to protect competition. And whether in the case of joint ventures, or the Section 19(3) provisions, it is doubtful that the Competition Commission will have the technical expertise to evaluate 'efficiency' in practice.

A possible alternative to case-by-case consideration of the balance between diminished competition on the one hand versus efficiency benefits on the other would be to exempt entire categories of agreements that are generally believed to be on the whole beneficial. In the EU, apart from $R \& D$ agreements, those relating to exclusive distribution and purchasing, franchising and technology licensing have been given 'block exemptions". In the Indian Competition Act, however, they remain subject to the 19(3) provisions on a case-by-case basis. Nor can these or other types of agreement be notified as exempt in future, for Section 54 allows the government (not the Competition Commission) to exempt only "any class of enterprises" in the public interest, or enterprises performing sovereign functions, or only those specific practices and agreements that may arise out of any obligation assumed by the government in an international agreement. Thus, ironically, a particular business practice can be exempted if an international agreement requires it to be exempted, but not if the government of India desires an exemption.

How important are these considerations in an international trade context? One can imagine a situation in which highly-paid lawyers representing the EU dairy industry argue before the Competition Commission that the Gujarat Cooperative Milk Marketing Federation (better known 
by its Amul brand name) is a price-fixing cartel, paving the way for massively subsidized European exports which have destroyed unorganized small-scale dairy farmers in many developing countries. (Agricultural cooperatives are exempted from provisions of antitrust laws by the Capper-Volsted Act in the US, while competition policy in the EU must defer to the Common Agricultural Policy.) Many agricultural exports are handled by large multinational agribusiness companies, who exert 'monopsony' power against small growers, resulting in a large gap between the prices that consumers in importing countries pay, and those that developing country producers receive. Allowing cartelization of the small exporters would go some way to level the playing field. But if the purchasing firm has a commercial presence in India, so that the initial transaction takes place within the country, then the automatic exclusion of export transactions in Section 3(5) will not apply. Thus, specific exemptions will be required. The case for such exemptions is equally strong in the case of certain manufactured exports, such as garments and footwear, that are supplied to large 'oligopsonistic' buyers from developed countries. Many developed countries provide exemptions in sectors characterized by unequal bargaining power, such as labour markets, agriculture, fisheries, and small firms that have to deal with large ones. ${ }^{21}$

Even in other industries, an unfamiliar and complex legal regime disproportionately burdens small firms with the costs of compliance, placing them at a competitive disadvantage relative to larger foreign rivals in a manner that has nothing to do with 'efficiency'. Therefore, if National Treatment requires the law to be applied equally to domestic and foreign firms, there is a strong case to grant exemptions for small firms participating in anti-competitive agreements in tradable sectors. In a country with no unemployment benefits, concerns about employment cannot be completely sacrificed for the sake of 'efficiency'. As I shall show in the next section, such concerns were decisive even in developed countries until recently. What needs to be kept in mind is that in saving employment in one industry, one should not sacrifice far more employment in other industries that use its product as an input. This was the basis of my critique of India's anti-dumping regime and of the MRTP Commission's injunctions against imports, which have protected large scale producers

\footnotetext{
${ }^{21}$ See the useful compilation in S. Khemani, Applications of Competition Law: Exemptions and Exceptions UNCTAD/DITC/CLP/Misc.25 (New York and Geneva: UNCTAD, 2002, available from www.unctad.org). Khemani believes that although some exemptions can be justified on economic grounds, many of them represent special interests, and calls for them to be time-limited and subjected to periodic review.
} 
and in the process hurt small scale and probably more employment-intensive users of their products.

Even for large firms, however, the ongoing restructuring of Indian industry could have been made more efficient and less painful if they had been allowed to enter into rationalization or specialization agreements, which are permitted in the EU. But as things stand there is no provision for allowing such agreements in India. The 'public interest' gateways of the MRTP Act will no longer be available. Although I have been critical of the way in which this construct was employed, a blanket prohibition of cartels has equally serious consequences. Foreign firms, being more experienced in dealing with similar technical clauses in their global operations, will be able to put up much better defences, and also escape penalties because they reside outside the Commission's reach. The burden of enforcement will be borne by their domestic rivals. A great deal is at stake, for unlike the modest fines of the MRTP Act, Section 27 of the Competition Act allows for heavy financial penalties amounting to ten per cent of turnover or three times the profits made by a cartel for contravention of Section 3.

Conversely, the Competition Act is inadequate to deal with blatantly anti-competitive cartels formed by large firms with no redeeming features. On this, the record of the MRTP Commission was quite dismal. Only 1.1 per cent of MRTP cases reported during 1991-98 involved Section 33(1)(d), which covers price-fixing and bid-rigging. ${ }^{22}$ In the five subsequent years, only four more cases have been decided by the MRTP Commission under this section. Three complaints were dismissed with the Commission pointing out that the Director General of Investigation had not been able to produce "even a whisper" of evidence of an agreement between the parties to raise their prices in concert. The fourth case, which involved fixation of service charges by the Indian Banks' Association, required no investigative effort as the evidence was easily available, in the form of an official IBA circular. However, even this case was disposed of on the grounds that the Reserve Bank of India had already given instructions to discontinue the practice. $^{23}$

\footnotetext{
${ }^{22}$ R. Basant and S. Morris, Competition Policy in India: Issues for a Globalising Economy, (Ahmedabad: Indian Institute of Management, 2000), p.157.

${ }^{23}$ This is based on an investigation of all RTP cases reported in the Consumer Protection Journal from 1999 to 2003. The handful of cases reported under Section 33(1) $(\mathrm{g})$, which relates to output restriction or market sharing agreements, all turned out to be cases against single firms rather than cartels.
} 
Thus, the investigative wing of the MRTP Commission has consistently failed to establish any covert conspiracy to fix prices, which is the essence of a cartel case. The new Competition Commission does not seem to have been armed with any greater powers to obtain evidence, and whether its budget and staffing will be any better remains to be seen. One potentially useful innovation in the new Act is a leniency clause for participants in a cartel who come forward with evidence that would be of use to the Commission. Such provisions have been extremely useful to competition authorities in other countries in gathering evidence against cartels. However, the leniency provision in the Competition Act is flawed. Section 46 of the Act allows for imposition of a reduced penalty on a participant in a cartel who makes a full disclosure of having violated the Act, provided that such disclosure is vital. But it provides that such reduction is discretionary, available only to the first participant who comes forward, and is not possible if any proceedings or even an investigation have already commenced. It also does not define what makes a disclosure 'vital'. On these matters, we have a lot to learn from the experience of other countries. For example, the amnesty schemes adopted in the US in 1978 and in the EU in 1996 remained largely ineffective for many years mainly because they were discretionary and did not apply after an investigation had begun. The US amended its scheme in 1993 to guarantee complete immunity to a firm that provided evidence to commence an investigation, and discretionary partial amnesty for providing useful evidence during the investigation which could be used to prosecute other cartel members. Consequently, the number of applications multiplied from about one a year to over twenty a year. In 2002, the EU modified its scheme along these lines, and South Korea introduced a very similar amnesty programme. Furthermore, these authorities already had a good track record in penalising cartels, so the threat of prosecution is real enough to induce firms to be the first to come forward so as to avoid penalties. Until the new Competition Commission of India establishes a similar reputation, it is unlikely that the leniency clause will be taken seriously.

\subsection{Implications for MAC negotiations}

India has been playing a major role amongst developing countries opposed to the idea of a MAC. Particularly noteworthy are the reasons it advanced in its communication to the Working Group as to why the arguments that make National Treatment vital in respect of trade in goods cannot be extended automatically to competition policy. As mentioned above, reductions of trade 
restrictions, the staple fare of GATT negotiations, could be easily undone if imports were subjected to discriminatory domestic taxes or regulations that disadvantaged them relative to their domestic competitors. NT prevents countries from engaging in this "behind-the-border" form of discrimination. But, as India argued, not all competition policy offences are trade distorting. At the same time, keeping NT out of a competition agreement would enable developing countries to join the emerging consensus against international cartels while permitting domestic cartels to rationalize production and enable orderly downsizing in the face of greater import competition. In the absence of social safety nets, this provision might be essential to enable developing countries to embrace further trade liberalization. The Indian submission also pointed out that since developing countries lack the resources to prosecute the anti-competitive practices of firms located abroad, domestic firms will in practice bear the brunt of a 'non-discriminatory' competition law. Even if the rules are nondiscriminatory, the costs of compliance will be higher for firms that are unfamiliar with them, putting firms in developing countries at a competitive disadvantage. ${ }^{24}$ All these are persuasive arguments. But just a few months later, Parliament passed the Competition Act, which is silent on the question of discrimination, thereby conceding de jure NT, which is what the EU wants. The EU submission left open the possibility of $\underline{\text { de facto }}$ discrimination in the form of discretionary implementation, but this is likely to be a potential area of conflict.

The EU Trade Commissioner was recently quoted as saying that India's opposition to a WTO agreement on competition is "only tactical because India's investment regime and competition law are already WTO-plus-plus". ${ }^{25}$ By enshrining both de jure National Treatment and a per se prohibition of hard-core cartels, the Competition Act has already conceded the EU's main objectives. WTO negotiations involve give and take; Members give concessions in exchange for making their own, either in the same agreement or in a different one being negotiated simultaneously. The Competition Act being already WTO-compliant in the eyes of the EU means that we have no bargaining chips, except an offer to bind these provisions in a WTO agreement before we wake up to their implications. This too would be problematic, as any departures will then become subject to dispute settlement and retaliation. The reintroduction of import restrictions as a remedy for foreign anti-competitive practices, apart from being self-defeating, is probably WTO-incompatible and

\footnotetext{
${ }^{24}$ WT/WGTCP/W/216.

25 'FDI behind India's stance: Lamy”, Business Standard, 15/16 March 2003, p.2.
} 
further complicates the situation.

\section{A critical evaluation of the case for a MAC}

In this section I shall deal with the case for a MAC as it existed at the stage when the WTO Working Group on Trade and Competition Policy suspended its discussions after the Cancun Ministerial. As we saw in Section 2 above, many of the matters that had been raised in its early years had been abandoned, and the key issues left on the table were international cooperation and the need to take action against international cartels. I shall now examine the case for a MAC under these two heads.

\subsection{Cartels and the 'development dimension' of competition policy}

Hard core cartels were the only RBP mentioned explicitly by the 2001 Doha Declaration for further exploration by the WTO Working Group on Trade and Competition Policy. In the Working Group itself, Members expressed concern over the varying definitions of hard-core cartels; whether some cartels, particularly export cartels, could be defended on grounds of efficiency, and the differing criteria applied for this purpose; the scope of exemptions granted by different Members; the merits of the "per se prohibition" versus "rule of reason" approaches; whether the WTO is the appropriate forum for international action; whether transparency required disclosure of enforcement priorities and case selection procedures; and the financial burden of introducing a competition law and setting up the necessary enforcement machinery. India's reservations in this regard were supported by countries such as Venezuela, Malaysia, Cuba, Hong Kong China, and Pakistan. ${ }^{26}$ The following paragraphs provide additional arguments against rushing into a multilateral agreement on competition policy, even if there is an overwhelming consensus on the harmful effects of cartels.

In one of his few writings on economic development, Harvard's Professor Frederic Scherer,

\footnotetext{
${ }^{26}$ See the minutes of the Working Group meeting of July 2002 (WT/WGTCP/M/18), paras 35, 36 and 39. Many of these concerns were raised again in the statement by developing countries on the eve of the Cancun Ministerial in September 2003 (WT/MIN(03)/W/4). The excerpts pertaining to competition policy are reproduced as Annexure C.
} 
the doyen of American competition policy specialists, agrees that international competition policy norms are in the interest of developing countries. ${ }^{27} \mathrm{He}$ believes that the developing countries' major gains from an agreement would come from two specific measures: first, as discussed in Section 2.3 above, replacing anti-dumping duties with competition policy principles governing predatory pricing would remove a major hindrance to developing countries' exports. Second, prohibition of export cartels based in developed countries that push up the prices of equipment and raw materials and also restrict the supply of licensed technology through cross-licensing of patents. Recognizing that there is likely to be resistance to prohibition of export cartels, Scherer had advocated that each country should be allowed to exempt upto three products at the four-digit SITC level. This provision contains a built-in differential treatment in favour of developing countries because a narrow range of such exports make up a larger share of their export basket. This point is worth considering, and can be extended also to manufactured products, for those countries who have established export-oriented industries. Unfortunately, minutes of the WTO Working Group make it clear that the United States is opposed to removing its blanket exemption of RBPs that have no domestic effects (which would include export cartels), ${ }^{28}$ and is united with the EU in opposing replacement of anti-dumping with competition rules, so these two sources of gains to developing countries are not likely to be forthcoming. 29

In an earlier book, which was one of the first monographs on international competition policy, Scherer reviewed the history of competition legislation in various countries. Since the EU is the chief proponent of a multilateral agreement, it is interesting to note that cartels were legal in Britain and France in the late nineteenth century, and cartel agreements could actually be enforced by the courts in Germany until the early twentieth century. The lessons of their early industrialization

\footnotetext{
${ }^{27}$ F.M. Scherer, 'International Competition Policy and Economic Development", in Competition Policy, Domestic and International (Cheltenham, UK: Edward Elgar, 2000). Similar views were expressed by C. Perroni and J. Whalley, 'Possible Developing Country Impacts from a Competition Policy Negotiation", in V.N. Balasubramanyam and D. Greenaway (eds), Trade and Development: Essays in Honour of Jagdish Bhagwati, ch.9, Basingstoke: Macmillan, 1996.

${ }^{28}$ Many other countries (including India, as noted in Section 4.2 above) have similar exclusions and exemptions. For a survey of country positions at the WTO on this issue, the prevalence and legal treatment of such cartels, and the arguments for and against them, see my paper 'Export Cartels: A Developing Country Perspective”, Journal of World Trade 38(2), April 2004.

${ }^{29}$ As I showed in Section 2.3 above, India has emerged in the last few years as a major user of antidumping, and most of its own actions would fail the tests required in predatory pricing cases, so it is probably quite willing to go along with this.
} 
experience would surely be more relevant to today's developing countries than their current policies. Again in the 1930s Depression, both Britain and Germany officially encouraged cartelisation, while crisis, rationalization and specialization cartels could be exempted in Germany as late as the 1990s. Although Britain enforced strict anti-cartel legislation under the 1956 Restrictive Trade Practices Act, it nonetheless gave an early exemption to an import cartel of sulphuric acid manufacturers in order to countervail a US export cartel. ${ }^{30}$

Extending Scherer's observation, historical research shows that competition policy was not geared exclusively to promoting efficiency, or even competition, in today's developed countries when they were in the early stages of development. Other social objectives were given more importance. Canada's 1889 Combines Investigations Act was the world's earliest antitrust statute, and according to one Canadian observer, 'In the earlier days of antitrust there were many pressures to use the law in the service of several goals, sometimes simultaneously - for example, as a weapon to fight big business, or to protect domestic firms from international competition, or simply to attack large firms for being large." ${ }^{, 31}$ Even in the U.S., the 1890 Sherman Act was passed as a populist measure to give the impression that the government was serious about controlling big business, and until the 1970s American antitrust policy was coloured by this consideration, as well as the objective of promoting small businesses even if they were less efficient. Although such concerns were abandoned in the U.S. with the ascendancy of the 'Chicago School' of antitrust, with its singleminded obsession with efficiency, they remain an important influence in Europe. As the World Bank has pointed out, 'In contrast with U.S. legislation, the EU's competition regime emphasizes equity objectives as well, such as employment and measures that encourage cooperation among small and medium enterprises". ${ }^{32}$ At the height of its economic miracle in the 1960s and 1970s, Japan exempted hundreds of cartels annually, mainly for exports and small and medium enterprises. ${ }^{33} \mathrm{It}$

\footnotetext{
${ }^{30}$ F.M. Scherer, Competition Policies for an Integrated World Economy (Washington: Brookings, 1994), pp.23-27, 53 and 56.

${ }^{31}$ T. Ross, 'Canadian Competition Policy: Progress and Prospects", Canadian Journal of Economics 37(2), May 2004, p.252.

${ }^{32}$ World Bank, World Development Report 2002: Building Institutions for Markets (New York: OUP, 2002), p.141, citing E.M. Graham and J.D. Richardson, Global Competition Policy (Washington, DC: Institute for International Economics, 1997).

${ }^{33}$ S. Nagaoka, 'International Trade Aspects of Competition Policy”. NBER Working Paper 6720,
} 
is thus ironic that Japan and the EU were leading the charge to impose uniform competition principles on other countries as part of a WTO agreement.

Yet another of Scherer's writings is worth citing at length in this context:

'First, there remain enormous differences across nations in the substance of national competition policies. Any multilateral accord will have to be on some limited subset of core principles governing only transactions with significant implications for international trade and/or investment. The most likely candidates are export and import cartels, serious abuses of dominant positions in the world market, and merger approval procedures. Second, even in these core areas, many nations will be unwilling to go all the way to a flat prohibition... Third, it must be recognized that historically, a considerable time interval passed before national competition policy enforcement agencies learned how to do their work. Seven years elapsed between passage of the US Sherman Act and the first Supreme Court prohibition of a price-fixing ring; twelve years between the Treaty of Rome and the first imposition of fines against EC cartels; eleven years between the creation of the UK Monopolies and Restrictive Trade Practices Commission and the first prohibition of a cartel by the Restrictive Practices Court; and twenty years between the post-occupation amendment of Japan's Anti-Monopoly Law and a Fair Trade Commission attack on illegal cartels, including the Commission's first criminal price-fixing indictment. Before serious enforcement can proceed, much learning must occur, and political support must be built."34

This unambiguous statement by a leading American expert should caution us against rushing into an over-ambitious multilateral agreement on cartels.

The best-known academic argument for such an agreement is that of Simon Evenett. He has advanced his case in very similar papers written for the WTO,${ }^{35}$ UNCTAD,${ }^{36}$ and an EU-funded

September 1998.

34 'International Trade and Competition Policy", in Competition Policy, Domestic and International, op.cit., p.27, emphasis added.

${ }^{35}$ S.J. Evenett, "Study on Issues Relating to a Possible Multilateral Framework Agreement on Competition Policy", WTO document WT/WGTCP/W/228, Geneva, 2003.

36 'Can Developing Economies Benefit from WTO Negotiations on Binding Disciplines for Hard Core Cartels?”, UNCTAD/DITC/CLP/2003/3, Geneva, 2003. 
project, ${ }^{37}$ basing it very largely on a 2001 study by Margaret Levenstein and Valerie Suslow commissioned by the World Bank. That study examined the evidence that emerged from the cases involving the forty-odd international cartels that had been prosecuted in the US and EU in recent years. It showed that the cartels affected a wide range of products, involved companies based in 31 countries, and appeared to have operated in various regions of the world. Many of the cartels lasted several years, and some of them attempted to punish rivals by instituting anti-dumping cases against them or denying them access to technology. Levenstein and Suslow estimated the value of developing countries' imports that were affected by the cartels, but Evenett goes much further in attempting to estimate the losses those countries might have suffered on account of being overcharged. He also refers to another study, conducted by himself and Julian Clarke, which estimates the overcharges of the notorious international vitamins cartel and shows that they were lower in countries with an active anti-cartel policy. On the basis of these findings, he argues that the costs of setting up the necessary enforcement mechanisms to control cartels will be easily exceeded by the savings to the countries from lower costs of their imports. After a few years of active enforcement the mere reputation for toughness will help to deter such cartels and further reduce the burden on the competition authorities. He also points out that if enforcement is extended to bidrigging cartels, then the government's own savings on its purchases of goods and services could offset the outlays on enforcement. However, he warns that allowing exemptions would harm consumers, and that implementing an approach based on the rule of reason rather than per se prohibition, would increase the burden on the competition authorities. He also warns that if countries are not compelled to take action against cartels, some of them will become safe havens for such activities, which adversely affect other Members.

Ironically, although commissioned at the request of countries like India who are opponents of a MAC, the study Evenett conducted for the WTO ends up endorsing the idea. Developing countries should not allow themselves to be enticed into an agreement by calculations of this kind, for if one delves into the methodologies adopted, one begins to recognize the frailty of the results. An updated version of the Levenstein-Suslow study makes several relevant points. ${ }^{38}$ First, to the

\footnotetext{
${ }^{37}$ P. Holmes, J. Mathis, T.C.A. Anant, and S.J. Evenett, 'The EU and India on Competition Policy at the WTO: Is There a Common Ground?", in L.A. Winters and P.S. Mehta (eds.) Bridging the Differences: Analyses of Five Issues of the WTO Agenda (Jaipur: CUTS, 2003) (accessible at www.cuts.org). The section of this paper on cartels was contributed by Evenett.

${ }^{38}$ M. Levenstein, V. Suslow and L. Oswald, 'International Price-Fixing Cartels and Developing Countries:
} 
extent that producers in developing countries benefited, whether in their own or export markets, from the price umbrella of the foreign cartels, any calculation of costs based only on losses to consumers is exaggerated. Second, Levenstein and Suslow only report the developing countries' imports of the products affected by the known cartels, being careful to acknowledge the methodological problems involved in comparing the product descriptions with those of SITC data on trade flows. The latter are broader in many cases, even at the 4-digit level, resulting in an overestimate of the value of cartel-affected imports. What the authors do not acknowledge is that looking at developing countries' total imports of the relevant products ignores the possibility that a significant proportion could have been supplied by exporters who were not cartel members. These exporters might have raised their own prices under the cartels' umbrella, but they might equally well have tried to undercut it. China seems to have played this role in a couple of the case studies in the paper. Ignoring the behaviour of such 'maverick' suppliers would again overestimate the cartels' effects.

Evenett ignores these problems, and calculates losses to developing countries as 20 to 40 per cent of the Levenstein-Suslow import figures. This percentage conforms roughly to the range of price increases found in the EU and US cartel cases. However, assuming the same markups for all countries ignores the fact of international price discrimination, or 'pricing to market', which is well established in the empirical international trade literature. Levenstein and Suslow's case study of the graphite electrodes cartel, for example, shows that the cartel underpriced its exports to India, attracting anti-dumping duties. Furthermore, in the revised version of their study, Levenstein and Suslow come up with a much lower figure for developing countries' imports of cartel-affected products in 1997 ( $\$ 54.7$ billion from 19 products, as against the $\$ 81.1$ billion for 16 products cited by Evenett from their earlier World Bank study). ${ }^{39}$

A Discussion of Effects and Policy Remedies", PERI Working Paper 53 (Amherst: University of Massachusetts, 2003). (Available from www.umass.edu/peri).

\footnotetext{
${ }^{39}$ On the other hand, Levenstein and Suslow's sample included only those cartels which were successfully prosecuted in the EU or US, and excluded from that list cartels in the services sector and those for which no reasonable match could be found in the trade data. These omissions would lead to an underestimate of the losses inflicted by cartels. With such large errors in both directions, Evenett' s WTO study gives a false sense of precision in comparing these estimated losses to magnitudes such as developing countries'
} 
The Clarke-Evenett paper avoids some of these problems by econometrically estimating the impact of the vitamins cartel on the value of vitamin imports of individual countries from countries where the cartels were known to operate, controlling for other determinants of bilateral trade flows and for vitamin exports from China, which were an important competitive influence. ${ }^{40}$ This is a promising advance, but the dummy variable they use to capture the effectiveness of a country's competition policy is very crude: a country reporting any action taken against a cartel to the OECD Global Forum on Competition Policy in 2001 or 2002 is classified as having 'active cartel enforcement' for all the years since 1985, or the year its national cartel law came into force, whichever is later. By this criterion, India is classified as not having active enforcement. But had India reported the MRTP injunction that was then in force against ANSAC (see Section 4.2 above), it would have been classified as having an active policy since 1985! Similar non-reporting might have resulted in misclassification of some of the 65 other countries categorized as not having active cartel enforcement; conversely, a country reporting a stray case of enforcement (to impress the OECD Forum?) would be classified as having an active enforcement record.

Even if we grant that international cartels are a serious problem, will a multilateral agreement help in curbing their activities? In an earlier published paper, Evenett, Levenstein and Suslow have themselves shown considerable scepticism about a WTO agreement being able to deliver the goods, for three cogent reasons. ${ }^{41}$ First, they present evidence that once cartels are detected, they take other forms such as mergers and joint ventures - and there is no proposal for an international agreement that will cover all these. I would like to extend this evidence from the 1990s cartels historically. Extensive merger activity took place amongst members of collusive agreements after the active

imports, competition agency budgets, aid receipts, and gains they would obtain from liberalization of agricultural policies by the developed countries.

${ }^{40}$ J.L. Clarke and S.J. Evenett, 'The Deterrent Effects of National Anti-Cartel Laws: Evidence from the International Vitamins Cartel”, (Washington, DC: AEI- Brookings Joint Center for Regulatory Studies Working Paper 02-13, 2002).

${ }^{41}$ S.J. Evenett, M.C. Levenstein, and V.Y. Suslow, 'International Cartel Enforcement: Lessons from the 1990s', The World Economy 24(9), September 2001, pp. 1221-45. Working paper version accessed from papers.ssrn.com. 
enforcement of the Sherman Act began in the USA in the early twentieth century, the Restrictive Trade Practices Act in the UK in the late 1950s, and Article 85 of the EEC Treaty of Rome in the 1960s. This eventually led to the extension of competition policy to merger control in each of these jurisdictions. Another form of collusion that would escape scrutiny is the pooling of patents by large corporations, with the agreements imposing restrictions on pricing and marketing of the products, and licensing of the technology (see Section 2.4 above). Several cases of denial of technology were documented by the Levenstein-Suslow research on international cartels. But this is an issue that has not been effectively dealt with by national competition policies, except through enforcing compulsory licenses in some countries. Since many developing countries have only recently instituted intellectual property regimes in conformity with the TRIPS agreement, they lack the expertise to examine such restrictive clauses in patents. The estimates of gains to be achieved from a successful prohibition of international cartels would have to be moderated to the extent that the cartels could take these different forms.

Second, Levenstein and Suslow argue that the widely diverging practices in Member countries will be difficult to reconcile in a way that can be codified in an agreement subject to WTO dispute settlement. Third, they cite a standard result from cartel theory according to which the gains from cartelization of firms that compete in many markets exceed their gains from cartelizing in each individual market. Cartelizing in a new market raises the cartel's profits in all the other markets it supplies. If firms weigh their prospective profits from cartelization against the probable legal penalties, this means that fines based on cartel profits in a single market (which is the most that a MAC will arrive at, since it leaves enforcement to national agencies) will be insufficient to deter cartels that operate in many countries. In their 2001 paper, Evenett et al concluded that 'For all these reasons a WTO agreement is, at present, unlikely to remedy the deficiencies of national anti-cartel enforcement".

Further, if one examines the illustrative list of restrictive agreements in the UNCTAD Set, one finds that it is broader than the concept of 'hard core' cartels employed by the OECD and the proponents of a multilateral WTO agreement. In addition to the price fixing, market sharing, and bid rigging agreements that are covered by hard core cartels, the Set also includes various forms of collective boycotts, including boycotts to enforce a collusive agreement (Section D.3, items (e) to 
(g)). It would be interesting to know from the proponents why such arrangements were kept out of the MAC proposal. Another way of punishing those producers who do not join an international cartel, or preventing them from sharing in its benefits, is to launch anti-dumping actions against them in the affected markets. The account of the graphite electrodes cartel in Evenett's papers mentions that Indian exporters were the victims of this strategy. But as mentioned repeatedly above, the major developed countries refuse to reform their anti-dumping procedures to conform to competition policy principles. A MAC that only requires countries to prohibit cartels will continue to be hamstrung if it does not confront these other practices that facilitate their operation.

The argument that non-enforcement of anti-cartel laws in some countries is likely to permit 'cartel havens' with negative spillovers on other countries ignores one crucial fact about national competition laws, highlighted in another section of the EU-sponsored report of which Evenett was a co-author: 'Domestic competition laws are jurisdictional with regard to effects on the domestic territory ... As such, they act to address both foreign and domestic practices, but only as these practices affect competition upon the domestic market." 42 As I pointed out above, most countries exclude RBPs that have effects only in foreign markets from the ambit of their competition laws. This means that a country could have an effective competition law, but still permit anti-competitive activities on its soil that adversely affect other countries.

On one point, however, I am in substantial agreement with Evenett. In submissions to the WTO WGTCP, India harped upon developing countries' right to implement an East Asian style industrial policy, allowing them to permit departures from the competitive norm in order to create firms that were 'national champions' so as to challenge the multinationals. I agree with Evenett (in his WTO paper, WT/WGTCP/W/228) that this argument is overstated. First, recent re-examinations of the East Asian case cited by him show that the industries that benefited from this policy were not necessarily the ones that became internationally competitive. Second, a restrictive policy towards trade and foreign investment, and directed credit, were the major instruments of this policy; competition policy was involved only to the extent that some mergers and cartels were permitted and encouraged by the state. Third, adoption of a competition law, or even adherence to a MAC, is not inconsistent with granting exemptions to those sectors where such a policy is to be implemented.

\footnotetext{
${ }^{42}$ Holmes et al., op cit, p.69.
} 
And in the Indian context, I would argue that the Indian state's ability to identify potentially efficiency enhancing mergers and cartels, to force firms to comply with its orders, and to enforce performance standards on them subsequently, is highly questionable.

\subsection{International Cooperation}

All WTO Members are agreed that effective action against international cartels requires close cooperation between competition agencies of different jurisdictions. The proponents of such an agreement frequently quote the 1998 OECD Recommendation Concerning Effective Action Against Hard Core Cartels. In this context it is important to note that even amongst the OECD members, where institutional convergence and communication are relatively more advanced, the Recommendation could go no further than to suggest greater sharing of information amongst the competition authorities of the member countries. A review report published by the OECD two years later noted that although the Recommendation had increased awareness about the effects of international cartels and the need for international cooperation to deal with them effectively, not much progress had been made on the latter front. Most competition agencies were still prevented from sharing even non-confidential information acquired in the course of an investigation, or tipping off agencies in other member countries about illegal conduct occurring in their jurisdiction. The report noted that

'In the few situations ...in which confidential information has been shared in competition cases, the record is one of improved enforcement and proper protection of confidential information. Moreover, in at least the securities, tax, customs, and criminal areas, it is common for enforcement authorities to be able to use compulsory process on behalf of foreign authorities and to share highly confidential information, and there too the record indicates that confidential information can be both protected and shared."43

A more recent review is more optimistic. ${ }^{44}$ It finds that international cooperation has increased markedly after 1999, but mainly in the form of informal exchanges on the nature of cases and evidence, the parties involved, and potential witnesses. Formal assistance in the collection of

${ }^{43}$ Hard Core Cartels, Paris: OECD, 2000. Quotation from p.15.

${ }^{44}$ Hard Core Cartels: Recent Progress and Challenges Ahead. Paris: OECD, 2003. 
evidence (searches, examination of witnesses, etc.) remained limited to a few countries with bilateral assistance agreements. In the vitamins and graphite electrodes cases, the review noted that other competition authorities came to know about the cartels and opened investigations when the prosecutions in the EU, US and Canada became public. In some cases this prompted cartel members to come forward and disclose their activities to their local competition authorities under leniency or amnesty programmes that allowed them to escape penalties in exchange for information that helped to prosecute other cartel members. However, these provisions themselves constitute a formidable barrier to international cooperation, for firms invariably agree to cooperate only on condition that their information not be used against them nor disclosed to any other authority. Otherwise they would be subject to "double jeopardy" for the same offence in different jurisdictions. In a few cases, some informal discussions with the US/EU authorities, and their supply of non-confidential information, helped the local authorities, although no details were made available. Many members complained that their efforts were hampered by non-availability of information available with foreign competition agencies, but protected by confidentiality restrictions. If this is the case even amongst OECD members after many years of consultations, it is unlikely that developing countries will be given much assistance.

We should also recall from Section 3.3 above that similar limited provisions for information sharing to deal with RBPs were enshrined in two existing multilateral agreements under the aegis of the WTO: Article IX of GATS and Article 40(3) of TRIPS. They required Members only to "accord full and sympathetic consideration" for requests for consultations from other Members and to cooperate "through the supply of publicly-available non-confidential information". Before proceeding to a more ambitious MAC, it would be worth examining to what extent these provisions have been used, and how effective they have been. Moreover, the EU and US will not contemplate a WTO MAC that would require them to extend cooperation on anything other than a voluntary basis to the competition authorities of other countries. They also oppose the extension of the WTO's MFN principle (prohibiting discrimination between Members) to the bilateral cooperation agreements they have entered into with each other and some selected partners. The US also insists that its export cartels will continue to be exempted from antitrust scrutiny, and that its laws do not allow for prosecuting firms that have adverse effects only on foreign parties. ${ }^{45}$ With no promise of effective

${ }^{45}$ See the country positions stated in the minutes of the Working Group meeting of July 2002, in 
international cooperation, developing countries are being asked to set aside financial and human resources to set up competition agencies and crack down on their own cartels, in pursuit of the mirage of the supposedly huge gains that will accrue to them once international cartels are magically brought to heel.

Even developing countries that already have competition agencies in place, and some experience of their working, are likely to lack the relevant enforcement capability. The kind of WTO agreement being proposed would merely require Members to enact non-discriminatory anti-cartel laws. If that were all that is needed to deal with the problem of cartels, then India's MRTP Act, the relevant sections of which were taken almost verbatim from the UK RTP Act, would have been a powerful weapon (at least until the Haridas ruling divested it of extra-territorial jurisdiction). But as we saw in Section 4.3 above, India's track record in prosecuting even domestic cartels is quite dismal, and in this respect the classification in the Clarke-Evenett study is accurate. If this is the situation as regards even domestic cartels, it would be unrealistic to expect any action against foreign cartels, where the evidence of conspiracy is much harder to obtain. The allegation of cartelization against ANSAC referred to in Section 4.2 was easy to prove because ANSAC had a distinct corporate identity and a membership agreement that explicitly mentioned fixing of prices as one of its objectives, and also disallowed its member firms from exporting individually. But most cartels are covert, with no formal agreement between the parties. We now have a new Competition Act that restores extra-territorial jurisdiction, and unlike its predecessor the MRTP Act, it makes participation in a hard core cartel a per se offence, incorporates a leniency clause to induce participants to reveal the conspiracy, and a section permitting international cooperation agreements. However, as I argued above, these provisions are unlikely to be effective for a long time.

\section{Recommendations for the future}

Before proceeding any further, let us remind ourselves that a specific WTO agreement is believed to be advantageous for a country for one or more of three reasons. First, the concessions a Member makes are in its own interest, and the agreement helps to lock them in and fend off pressure

WT/WGTCP/M/18. 
from narrow domestic interests who would like to reverse them. Second, because the concessions other WTO Members make in that particular agreement are in its interest. Third, the concessions they make in other agreements, as part of a grand bargain in cross-sector negotiations, are in its interest. The arguments advanced in the two preceding sections show that a MAC that would only require Members to impose a non-discriminatory prohibition on cartels operating in their own territories fails to bring benefits on all three counts. It is not in India's own interest to prohibit all domestic cartels; in the absence of substantive international cooperation, it will not give us any greater leverage against foreign cartels; and there are no meaningful concessions that India can make in a MAC in exchange for concessions in other agreements.

For all these reasons, domestic as well as international, I believe that India should resist a multilateral agreement on competition at the WTO. At the same time, it is undeniable that anticompetitive activities have a cross-border dimension that adversely affects trade and development, and international cooperation is essential to deal with it. Ideally, any agreement should be plurilateral and outside the WTO Single Undertaking, allowing Members to sign in when they are prepared and to sign out if they find it too costly, without prejudice to their rights under other agreements. Such an agreement could be outside the WTO framework altogether, perhaps under the aegis of UNCTAD, which is perceived as more friendly to developing countries and also has a good record in analysing multinational corporations and their activities. It has also drawn up a model competition law and a model cooperation agreement to serve as templates for interested countries, and has generated considerable useful documentation and information sharing in holding the annual meetings of the Intergovernmental Group of Experts as well as the quinquennial conferences to review the non-binding UNCTAD Set. The next review conference is scheduled for 2005, and could be used to lay the foundation for a more formal structure.

A parallel process seems to have started in the OECD. For several years, it has been inviting non-members to meetings of its Global Forum on Competition to compare experiences in this field. More recently, following its Monterrey Consensus and Johannesburg Initiative, identifying promotion of private investment as a vital component of development, it has set up a Task Force to develop a Policy Framework for Investment with competition policy as one of the building blocks. By holding the most recent meeting (October 2004) of the Task Force in New Delhi in collaboration 
with the Confederation of Indian Industry, the OECD seems to be signalling its intention to engage countries like India more actively in this process. Although OECD documents claim that the process involves stocktaking of best practices across countries so as to evolve a non-prescriptive checklist for interested governments, developing countries should be wary of attempts by the developed countries that dominate the OECD to introduce a MAC or MAI (multilateral agreement on investment) through the backdoor, having failed at the WTO.

These international organizations have a heavy representation from developed countries, of course much more so in the OECD than in UNCTAD. Therefore, developing countries should interact more with each other to formulate a consensus that better represents their own interests. Brazil, Mexico, South Africa and South Korea are probably the developing countries with the most active competition agencies, with much better records in dealing both with cartels and with crossborder issues. India should engage with them without insisting that its larger size and MRTP experience gives it any greater qualifications on these matters. Apart from interactions between official agencies, civil society organizations (universities, think tanks, research institutes and NGOs) in developing countries should develop their own competencies and communicate with each other, if necessary by drawing on the considerable funding that is being made available by aid agencies in developed countries.

These discussions could ultimately result in an agreement. The model should be the international agreements on trade in hazardous substances and genetically modified organisms, where information sharing is central, rather than enforcement subject to dispute settlement. Other aspects that could be embodied in such an agreement would be creation of a forum for consultation, experience sharing, voluntary cooperation, capacity building, and non-adversarial peer review of national policies, without any binding obligations. Two of Evenett's proposals (as spelt out in the three papers cited above) are worth including in this framework. One is creating a central clearinghouse for dissemination of information on anti-cartel investigations and non-confidential case materials, perhaps requiring countries to notify the relevant cases to this clearing house. This would at least alert other countries to the activities of firms that might also be operating in their domains. The other is to weaken the protection given to confidential evidence disclosed under leniency programmes by having countries commit to extending at least the same degree of leniency (in the 
form of reduced fines) in exchange for information relevant to the firms' activities in their jurisdictions, which could provide evidence to prosecute other cartel members. These proposals do not require a WTO agreement; in fact the second could be implemented unilaterally by countries without any kind of international agreement.

In the closing stages of the WGTCP discussions, some developing-country delegations (particularly India and Thailand) pressed for an agreement that would force developed countries to abolish their exemption of RBPs whose effects were felt only in foreign markets. Instead, they should prosecute their own firms when they engage in such practices affecting developing countries, while the latter would not be required to reciprocate. Some scholars have also suggested an agreement along similar lines, perhaps in return for market access (trade liberalisation) concessions by developing countries. ${ }^{46}$ Another proposal is that an international antitrust agency should be set up to undertake investigation, adjudication and imposition of remedies on firms that engage in crossborder RBPs, and on multinationals that propose mergers that would impair competition. ${ }^{47}$ Politically, however, these proposals seem to be out of the question, given the opposition from the developed countries. Therefore, although much can be sought in the area of international cooperation and information sharing, enforcement would have to remain the responsibility of domestic competition authorities, determined by their own priorities and resources rather than external commitments.

In this context, I would like to suggest a novel approach, based on parallels with antidumping (AD) procedures, that could lighten the evidentiary burden of prosecuting both multicountry international cartels and single-country export cartels. ${ }^{48}$ The Uruguay Round AD agreement allows much greater latitude for countries to address dumping than do standard competition law approaches to discriminatory or predatory pricing. In recent debates on the interaction between trade

\footnotetext{
${ }^{46}$ For example, B. Hoekman and P.C. Mavroidis, 'Economic Development, Competition Policy and the WTO”, Journal of World Trade 37(1-27), February 2003.

${ }^{47}$ A. Singh, 'Multilateral Competition Policy and Economic Development: A Developing Country Perspective on the European Community Proposals", UNCTAD document UNCTAD/DITC/CLP/2003/10.

${ }^{48}$ The following is a more elaborate version of a set of proposals first put forward in my paper 'Export Cartels", op. cit.
} 
and competition policy, many scholars argued that application of antitrust standards would help to curb the abuse of AD procedures - but, as pointed out above, developed countries consistently refused to accept this suggestion. The relaxed standards of $\mathrm{AD}$ could, with much greater justification, be applied to foreign cartels whose overcharging is after all the mirror image of dumping. (Indeed, it is sometimes referred to as "reverse dumping"). For example, instead of requiring proof of a pricefixing conspiracy, the enforcement agency could be required to demonstrate that the price exceeds some "hormal value". ${ }^{49}$ As with $\mathrm{AD}$, this could be assessed on the basis of best information available regarding the firms' costs, or the prices they charge in their own or other markets, with suitable adjustment for transport costs. The Clarke-Evenett study referred to above tried to show that international cartels charge lower prices in countries with active competition agencies. Although I have expressed reservations about their methodology, to the extent the finding is true, the price comparison suggested here would allow agencies in poor countries to free ride on the activities of their better equipped and experienced peers, without their explicit cooperation. Other leaves that could be taken from the AD book include norms for defining a "like product" (to avoid penalising firms which sell different varieties in different countries); retroactive assessment; and provisional measures requiring bonds or advance deposits from respondent firms while the case is pending.

Obviously, some provisions of the AD agreement would not carry over to this scheme, such as the standing given to domestic producers as complainants in a dumping case, or the requirement that they prove that they have been injured by the dumped imports. Although reverse dumping places domestic consumers in an analogous position, there is an insuperable 'free rider' problem in expecting them to initiate action or shoulder the burden of proof. Unlike producers who suffer from low-priced imports, consumers who suffer from the opposite are typically very dispersed and the injury to each one would be insufficient to make it worthwhile to file a petition. The costs of organising a collective petition would be prohibitive. Consumer organisations could act on their behalf, but they too would find it very difficult to gather evidence of a cartel conspiracy located in

\footnotetext{
${ }^{49}$ Even for domestic antitrust enforcement, no less an authority than the American judge and legal scholar Richard Posner has argued for a move away from the traditional "cops and robbers" approach based on uncovering conspiracies towards one based on economic evidence of collusion, including price discrimination and regional price variations. See R. Posner, Antitrust Law, Chicago: University of Chicago Press, 2001, ch.3.
} 
another country. Instead, the inquiry could be triggered by an abnormal rise in import prices, registration of the cartel in its home country, or by investigations being carried out against the same firms in other jurisdictions. Evidence of this nature could even be deemed sufficient to create a rebuttable presumption of cartelization, reversing the burden of proof.

Like AD petitions, this procedure would not require the evidentiary standards (and hence cooperation from the respondents and their governments) of an antitrust case. Countries whose competition agencies are denied such cooperation could consider unilaterally applying these relaxed standards to foreign firms. Although the Dispute Settlement Panel in the 1997 Kodak-Fuji case held that national competition laws were subject to the core WTO principle of National Treatment, discrimination of this kind cannot be said to be trade-restricting, and would arguably not constitute an infringement of GATT obligations. (This point might be worth settling in a test case that led to formal dispute settlement proceedings.) If the issue of a multilateral agreement on competition policy were to be revived, despite its apparent demise at Cancun, developing countries could press for one along the lines suggested above. This would give them a better chance of taking on foreign cartels than the agreement envisaged by the EU, while laying down procedures, rules of evidence, and permissible penalties so as to safeguard the other WTO principles of transparency and procedural fairness, and prevent protectionist abuse.

A bolder proposal, particularly appropriate for products like pharmaceuticals and specialty chemicals whose producers are notorious for their cartel activities, would be a WTO agreement on competition policy that would allow Members to suspend the offending firms' rights under the TRIPS agreement, either by revoking their patents and allowing free use by domestic firms, or by issuing compulsory licenses. The more usual kind of retaliation takes the form of suspending concessions under the GATT, which involves increasing tariffs on a range of the violating country's exports. Thus, it is likely to inflict a welfare loss on the retaliating country itself, and also on exporters who had nothing to do with the violation. In contrast, cross-agreement retaliation against the offending firms in a cartel case in the form of suspension of their patent rights would not involve self-injury by the retaliating country, and be precisely targetted on the beneficiaries of the impugned conduct. If they do not supply patented products to the country in question, then the patents of other industries in the supplying country can be targetted. 
Retaliation under TRIPS needs to be considered more generally. Paragraph 22 of the WTO Understanding on Dispute Settlement already allows countries to retaliate against other Members who are found to violate an agreement, by suspending concessions made to them in the same broad 'sector' (defined as goods, classes of services under GATS, or specific categories of IPRs under TRIPS). Where this is not feasible, concessions made under other agreements can be withdrawn. A few years ago, Ecuador was allowed to suspend concessions under TRIPS when the Dispute Settlement Body found in its favour in its dispute with the EU, concerning the latter's banana import regime. Ecuador did not in fact undertake retaliation, as it did not find it in its interest to do so, but the principle of cross-agreement retaliation has been established. After TRIPS comes into full force in 2005, this may be used in the reverse direction by developed countries to penalise developing countries that violate their patents. Most developing countries do not own significant IPRs, and therefore cannot be retaliated against by suspending concessions under the TRIPS agreement itself. Retaliation is more likely to be effective if it takes the form of suspending concessions made under other agreements where developing countries have much to lose, such as textiles, clothing and agriculture. Developing countries should consider arming themselves with retaliatory capability in the TRIPS domain, where the developed countries are vulnerable.

In the Uruguay Round Agreement on Textiles and Clothing (ATC), developed countries committed themselves to terminate the Multifibre Arrangements that restrict developing countries' exports of these products by the end of 2004. Aaditya Mattoo and Arvind Subramanian have recently suggested that India should suspend developed countries' rights under the TRIPS in order to retaliate against any attempt by them to renege on their commitment. ${ }^{50} \mathrm{My}$ own proposal can be seen as a variant of this. But unlike the Mattoo-Subramanian proposal, it would require a new WTO agreement, because while reneging on ATC would be a violation of existing commitments by developed countries, which would entitle developing countries to retaliate, firms have no obligations under existing agreements to refrain from RBPs. However, a hybrid of two existing agreements could provide the necessary building blocks for this proposal, for targetting of firms rather than

\footnotetext{
${ }^{50}$ See Subramanian, 'India as User and Creator of Intellectual Property: The Challenges Post-Doha", and Mattoo and Subramanian, 'India and the Multilateral Trading System Post-Doha: Defensive or Proactive", respectively chapters 8 and 13 in A. Mattoo and R.M. Stern (eds.), India and the WTO, Oxford University Press and the World Bank, 2003.
} 
Member countries is already well-established in the Agreement on Anti-Dumping and the TRIPS provisions on compulsory licensing. As noted in Section 3.3 above, Article 31(k) of the TRIPS agreement already relaxes the conditions under which a compulsory licence may be issued in order to remedy an anti-competitive practice. But the mechanism I am suggesting here is not to remedy an abuse, but primarily to retaliate and secure compensation from offending firms. It would therefore permit Members to issue compulsory licences for products produced by cartelizing firms other than the cartelized product itself. For example, suppose that pharmaceutical firms are found to be participating in a vitamins cartel. As this product is not patented, a compulsory licence has no value. Instead, other front-line patented drugs produced by the same firms would be licensed, penalising the offenders and partially compensating the importing country, if not the consumers who were actually victims of the cartel. More generally, the GATT/WTO framework, as it stands, confers valuable rights (market access, intellectual property protection) on firms, with no reciprocal obligations. Suspension of those rights would be an appropriate penalty for anti-competitive behaviour.

\section{Summary and conclusions}

In Section 1 of this monograph, after introducing the elements of competition policy and various views on its relevance for developing countries, I briefly reviewed the intermittent international discussions that took place on cross-border competition policy issues in the half-century preceding the 1996 Singapore Ministerial which brought them onto the WTO stage. Section 2 examined five arguments that were advanced in the course of the subsequent debate: harmonization of national competition laws to promote foreign investment; dismantling private barriers to market access; prevention of abuse of anti-dumping procedures by replacing them with stricter antitrust standards; prevention of abuse of intellectual property rights; and action against cross-border cartels. The first four arguments did not go very far due to sharp differences between members, and even the 2001 Doha Declaration's narrower focus on the fifth one and the general provisions of a MAC ran into difficulties in subsequent discussions. I summarised the broad contours of this debate and the various compromise solutions that were put forward before the entire issue was put into cold storage after the impasse at the 2003 Cancun Ministerial. 
Section 3 undertook a detour to examine existing competition-policy related agreements, beginning with bilateral, trilateral and regional agreements. I then looked at the UNCTAD Set, which is the most inclusive in terms of national membership and issues covered, and yet the least effective. The section concluded with an examination of the applicability of the National Treatment clause of the GATT to domestic competition laws, and provisions that are directly concerned with competition policy in three existing WTO agreements (Safeguards, GATS and TRIPS). I noted that there had been as yet very little evidence of how these provisions had been implemented by various countries and interpreted by the WTO Dispute Settlement Body. Section 4 turned the spotlight back on India, which is in transition between an old and new competition law. I welcomed some of the positive features of the new Competition Act, but expressed concern about many of its sections dealing with cross-border issues. In particular, the power it grants to the Competition Commission to order injunctions against imports could be misused to restrict competition rather than to promote it. Lack of expertise to interpret many of its technical provisions will hamper its implementation and also our ability to secure cooperation from foreign agencies. It will penalise small producers and let the big ones, especially foreign firms with experience in dealing with such provisions in many countries, get away with similar infractions. In particular, it is unlikely to be effective against foreign cartels.

Section 5 returned to the WTO debate and critically examined the case for an agreement directed against cartels. I reviewed the historical experience to show that an entirely hostile approach towards domestic cartels was not advisable, and that the highly-publicised calculations regarding the costs inflicted on developing countries by international cartels were methodologically questionable. In any case, I argued that such cartels could not be tackled effectively by an agreement of the kind being proposed, as it neglected various other practices used to facilitate their functioning, and it also made no substantive provision for the international cooperation that is necessary to deal with them. Nevertheless, recognizing that such cartels do pose a problem, in Section 6 I advanced suggestions for gradually moving towards a limited international agreement outside the WTO, concentrating on information sharing, consultations and capacity-building. For giving teeth to enforcement, I also proposed a more radical agreement that would reduce the evidentiary standards for identifying foreign cartels, and would permit developing countries to penalise them by suspending their intellectual property rights. 
Preparing the ground for such measures, and also remedies for issues like abuse of IPRs and RBPs restricting market access that were abandoned in the early stages of the WTO discussions, would require considerable effort on the part of developing countries to equip themselves with the appropriate technical skills in the legal and economic principles in the areas of both antitrust as well as intellectual property. They would also have to form collaborative relationships between their official and non-official bodies concerned with competition policy in order to promote their own understanding of these issues and to resist the imposition of unsuitable approaches by the developed countries. These efforts towards capacity building and cooperation should involve not just the competition agencies in these countries, but also the wider academic and NGO communities. 


\section{ANNEXURES \\ Annexure A \\ Excerpt from the WTO Singapore Ministerial Declaration (WT/MIN(96)/DEC), paragraph 20}

(Adopted 13 December 1996)

20. Having regard to the existing WTO provisions on matters related to investment and competition policy and the built-in agenda in these areas, including under the TRIMs Agreement, and on the understanding that the work undertaken shall not prejudge whether negotiations will be initiated in the future, we also agree to:

- establish a working group to examine the relationship between trade and investment; and

- establish a working group to study issues raised by Members relating to the interaction between trade and competition policy, including anticompetitive practices, in order to identify any areas that may merit further consideration in the WTO framework.

These groups shall draw upon each other' s work if necessary and also draw upon and be without prejudice to the work in UNCTAD and other appropriate intergovernmental fora. As regards UNCTAD, we welcome the work under way as provided for in the Midrand Declaration and the contribution it can make to the understanding of issues. In the conduct of the work of the working groups, we encourage cooperation with the above organizations to make the best use of available resources and to ensure that the development dimension is taken fully into account. The General Council will keep the work of each body under review, and will determine after two years how the work of each body should proceed. It is clearly understood that future negotiations, if any, regarding multilateral disciplines in these areas, will take place only after an explicit consensus decision is taken among WTO Members regarding such negotiations. 


\section{Annexure B}

\section{Excerpt from the WTO Doha Ministerial Declaration (WT/MIN(01)/DEC/1), paragraphs 23-25}

(Adopted 14 November 2001)

\section{INTERACTION BETWEEN TRADE AND COMPETITION POLICY}

23. Recognizing the case for a multilateral framework to enhance the contribution of competition policy to international trade and development, and the need for enhanced technical assistance and capacity-building in this area as referred to in paragraph 24, we agree that negotiations will take place after the Fifth Session of the Ministerial Conference on the basis of a decision to be taken, by explicit consensus, at that Session on modalities of negotiations.

24. We recognize the needs of developing and least-developed countries for enhanced support for technical assistance and capacity-building in this area, including policy analysis and development so that they may better evaluate the implications of closer multilateral cooperation for their development policies and objectives, and human and institutional development. To this end, we shall work in cooperation with other relevant intergovernmental organizations, including UNCTAD, and through appropriate regional and bilateral channels, to provide strengthened and adequately resourced assistance to respond to these needs.

25. In the period until the Fifth Session, further work in the Working Group on the Interaction between Trade and Competition Policy will focus on the clarification of: core principles, including transparency, non-discrimination and procedural fairness, and provisions on hard core cartels; modalities for voluntary cooperation; and support for progressive reinforcement of competition institutions in developing countries through capacity-building. Full account shall be taken of the needs of developing and least-developed country participants and appropriate flexibility provided to address them. 


\section{Annexure C}

\section{Excerpts from a Communication from developing countries regarding the Singapore Issues (WT/MIN(03)/W/4)}

The following communication, dated 2 September 2003, has been received from the Permanent Mission of India on behalf of the above delegations.

On behalf of the delegations of Bangladesh (on behalf of the LDC Group), Botswana, China, Cuba, Egypt, India, Indonesia, Kenya, Malaysia, Nigeria, Philippines, Tanzania, Uganda, Venezuela, Zambia and Zimbabwe, I write to request you to circulate the joint communication contained in document WT/GC/W/514, dated 28 August 2003, as a formal Ministerial Conference document.

In paragraphs 13, 14, 15 and 16 of the draft Ministerial Text dealing with Singapore Issues, two options have been indicated, one expressing the proponents' view and the other of those who favour continuation of the clarificatory process. The sharp difference of view among Members on these issues does not offer any other choice.

However, the Annexes D, E, F and G to the Draft Ministerial text, that reflect the view of proponents on the modalities, gives a distorted view, that the Annexes have been discussed by Members. It would be recalled that the text on transparency in government procurement was introduced by the proponents in a small group meeting. We are not aware of any text having been put forward by the proponents on trade facilitation. The text on competition policy was discussed only in a small group meeting. Only the proponents' paper on investment was introduced and discussed inconclusively in the HOD level meeting. Thus, Members did not have an opportunity to discuss the modalities identified by the proponents in all the Annexes to the Draft Ministerial text.

There was lack of clarity on how these issues will be dealt with in the draft Ministerial text, 
due to which Members, who favour continuation of the clarificatory process, could not put forward their views on the issues for further clarification in the form of a paper, though they had expressed their views in detail during the consultations. My delegation along with those of Bangladesh (on behalf of the LDC Group), Botswana, China, Cuba, Egypt, Indonesia, Kenya, Malaysia, Nigeria, Philippines, Tanzania, Uganda, Venezuela, Zambia and Zimbabwe have jointly identified issues that require further clarification in the respective Working Groups/CTG. These are reflected in the Annexes to the letter.

In the interest of balance in reflecting the broad spectrum of views on these issues in the Draft Ministerial text, we would like to request you to add these Annexes to the draft text to be transmitted to the Ministers. In addition, we would request that this letter together with Annexes be circulated to all the Members as a formal document of the General Council, so that every Member is aware of the views of our delegations on this important issue.

$[\ldots]$ 


\section{Trade and Competition Policy \\ Issues for further clarification in the Working Group}

Non-discrimination:

(i) Implication of the principle of national treatment on the policy space enjoyed by developing and least developed Members for pursuing industrial, social and other development strategies.

(ii) Scope of application of the principle of non-discrimination.

(iii) Further clarification of the relationship between any multilateral framework and existing bilateral and regional arrangements on trade and competition policy.

Transparency: Clarity on the requirement to notify or publish decisions taken in individual cases; would the transparency requirements cover disclosure of enforcement priorities, case selection criteria, exemption criteria and principle of derogation?

Hardcore Cartels: Clarification on the definition of hardcore cartels, including the role of export cartels; would the criteria for prohibition of such cartels be based on 'per se' or 'rule of reason' approach? What would be the scope of exemption from general prohibition on hardcore cartels? It is understood that inter-governmental arrangements are to be excluded from the definition.

International Co-operation: Further clarification on the likely burden on developing and least developed Members for providing information sought by developed Members and the means to compensate them for their efforts. Would voluntary cooperation limit the ability of developing and least developed Members to receive co-operation from developed Members in investigation of anti-competitive practices? What would be the norms for exchange of non-confidential information, etc?

Compliance Mechanism: Clarification on the scope of applicability of DSU and/or peer review in this area. 


\title{
Annexure D \\ Excerpt from the Decision of the WTO General Council on the Doha Work Programme (WT/L/579), paragraph 1(g)
}

(adopted 1 August 2004)

\begin{abstract}
Relationship between Trade and Investment, Interaction between Trade and Competition Policy and Transparency in Government Procurement: the Council agrees that these issues, mentioned in the Doha Ministerial Declaration in paragraphs 20-22, 23-25 and 26 respectively, will not form part of the Work Programme set out in that Declaration and therefore no work towards negotiations on any of these issues will take place within the WTO during the Doha Round.
\end{abstract}

